\title{
Reconstitution of the complete rupture in musculotendinous junction using skeletal muscle-derived multipotent stem cell sheet-pellets as a "bio-bond"
}

\author{
Hiroyuki Hashimoto ${ }^{1,2}$, Tetsuro Tamaki ${ }^{\text {Corresp., }}{ }^{2,3}$, Maki Hirata ${ }^{1,2}$, Yoshiyasu Uchiyama ${ }^{1,2}$, Masato Sato ${ }^{1}$, Joji \\ Mochida ${ }^{1}$ \\ 1 Department of Orthopedics, Tokai University School of Medicine, Isehara, Japan \\ 2 Muscle Physiology and Cell Biology Unit, Department of Human Structure and Function, Tokai University School of Medicine, Isehara, Japan \\ 3 Department of Human Structure and Function, Tokai University School of Medicine, Isehara, Japan \\ Corresponding Author: Tetsuro Tamaki \\ Email address: tamaki@is.icc.u-tokai.ac.jp
}

Background. Significant and/or complete rupture in the musculotendinous junction (MTJ) is a challenging lesion to treat because of the lack of reliable suture methods. Skeletal muscle-derived multipotent stem cell (Sk-MSC) sheet-pellets, which are able to reconstitute peripheral nerve and muscular/vascular tissues with robust connective tissue networks, have been applied as a "bio-bond". Methods. Sk-MSC sheet-pellets, derived from GFP transgenic-mice after 7 days of expansion culture, were detached with EDTA to maintain cell-cell connections. A completely ruptured MTJ model was prepared in the right tibialis anterior (TA) of the recipient mice, and was covered with sheet-pellets. The left side was preserved as a contralateral control. The control group received the same amount of the cell-free medium. The sheet-pellet transplantation (SP) group was further divided into two groups; as the short term (4-8 weeks) and long term (14-18 weeks) recovery group. At each time point after transplantation, tetanic tension output was measured through the electrical stimulation of the sciatic nerve. The behavior of engrafted $\mathrm{GFP}^{+}$tissues and cells was analyzed by fluorescence immunohistochemistry. Results. The SP short term recovery group showed average $64 \%$ recovery of muscle mass, and $36 \%$ recovery of tetanic tension output relative to the contralateral side. Then, the SP long term recovery group showed increased recovery of average muscle mass (77\%) and tetanic tension output (49\%). However, the control group showed no recovery of continuity between muscle and tendon, and demonstrated increased muscle atrophy, with coalescence to the tibia during 4-8 weeks after operation. Histological evidence also supported the above functional recovery of SP group. Engrafted Sk-MSCs primarily formed the connective tissues and muscle fibers, including nerve-vascular networks, and bridged the ruptured tendon-muscle fiber units, with differentiation into skeletal muscle cells, Schwann cells, vascular smooth muscle, and endothelial cells. Discussion. This bridging capacity 
between tendon and muscle fibers of the Sk-MSC sheet-pellet, as a "bio-bond", represents a possible treatment for various MTJ ruptures following surgery. 
1 Reconstitution of the complete rupture in musculotendinous

2 junction using skeletal muscle-derived multipotent stem cell

3 sheet-pellets as a "bio-bond"

5 Hiroyuki Hashimoto ${ }^{1,2}$, Tetsuro Tamaki ${ }^{2,3}$, Maki Hirata ${ }^{1,2}$, Yoshiyasu Uchiyama ${ }^{1.2}$,

6 Masato Sato ${ }^{1}$, Joji Mochida ${ }^{1}$.

7

$8 \quad{ }^{1}$ Department of Orthopedics,

$9 \quad{ }^{2}$ Muscle Physiology and Cell Biology Unit,

$10{ }^{3}$ Department of Human Structure and Function,

11 Tokai University School of Medicine, 143 Shimokasuya, Isehara, Kanagawa 259-1193

12 Japan.

13

Correspondence to: Tetsuro Tamaki, $\mathrm{PhD}$

Muscle Physiology and Cell Biology Unit, Department of Human structure and

18 Function, Tokai University School of Medicine

19 143-Shimokasuya, Isehara, Kanagawa 259-1143 Japan.

20 Tel: +81-463-93-1121 (ext.2524); Fax: +81+463-95-0961

21 E-mail: tamaki@is.icc.u-tokai.ac.jp 


\section{Manuscript to be reviewed}

24

\section{ABSTRACT}

Background. Significant and/or complete rupture in the musculotendinous junction (MTJ) is a challenging lesion to treat because of the lack of reliable suture methods. Skeletal muscle-derived multipotent stem cell (Sk-MSC) sheet-pellets, which are able to reconstitute peripheral nerve and muscular/vascular tissues with robust connective tissue networks, have been applied as a "bio-bond".

Methods. Sk-MSC sheet-pellets, derived from GFP transgenic-mice after 7 days of expansion culture, were detached with EDTA to maintain cell-cell connections. A completely ruptured MTJ model was prepared in the right tibialis anterior (TA) of the recipient mice, and was covered with sheet-pellets. The left side was preserved as a contralateral control. The control group received the same amount of the cell-free medium. The sheet-pellet transplantation (SP) group was further divided into two groups; as the short term (4-8 weeks) and long term (14-18 weeks) recovery group. At each time point after transplantation, tetanic tension output was measured through the electrical stimulation of the sciatic nerve. The behavior of engrafted $\mathrm{GFP}^{+}$tissues and cells was analyzed by fluorescence immunohistochemistry.

Results. The SP short term recovery group showed average $64 \%$ recovery of muscle mass, and $36 \%$ recovery of tetanic tension output relative to the contralateral side. Then, the SP long term recovery group showed increased recovery of average muscle mass (77\%) and tetanic tension output (49\%). However, the control group showed no recovery of continuity between muscle and tendon, and demonstrated increased muscle atrophy, with coalescence to the tibia during 4-8 weeks after operation. Histological evidence also supported the above functional recovery of SP group. Engrafted Sk-MSCs primarily formed the connective tissues and muscle fibers, including nerve-vascular 
48 networks, and bridged the ruptured tendon-muscle fiber units, with differentiation into

49 skeletal muscle cells, Schwann cells, vascular smooth muscle, and endothelial cells.

50 Discussion. This bridging capacity between tendon and muscle fibers of the Sk-MSC

51 sheet-pellet, as a "bio-bond", represents a possible treatment for various MTJ ruptures

52 following surgery.

53

54 Key words: nerve reconstitution, vascular reconstitution, muscle regeneration, tendon 55 regeneration, stem cell therapy. 


\section{INTRODUCTION}

Skeletal muscles represent muscle-tendon complexes attached to the bone.

However, due to their roles in the protection of the body and the force generation at the body-movements, injuries invariably occur during various activities or as a result of accidents. Muscle injuries can be classified as ruptures, tears, and lacerations, typically caused by external hard compression (contusion) or excessive stretching forces, and they are categorized into 3 grades of severity, as follows: Grade-I (mild) injury affects only a limited number of fibers in the muscle, and the strength does not decrease in the full active and passive range of motions, with pain and tenderness being delayed until the next day; Grade-II (moderate) injury, where nearly half of muscle fibers are torn, and acute and significant pain is accompanied by swelling and a minor decrease in muscle strength; Grade-III (severe) injury, with the complete rupture of the muscle, where the injured muscle is torn into 2 parts, together with severe swelling and pain, and a total loss of function. The injuries can be broadly divided according to their location in the muscle belly, musculotendinous junction (MTJ), and tendon tear (Chan et al. 2012; ElMaraghy \& Devereaux 2012). Generally, for Grade-I and -II injuries, conservative treatments are usually applied, but in the case of Grade-III injuries, surgical intervention is often considered (Kragh et al. 2005c; Oliva et al. 2013; Rawson et al. 2013). Several suturing techniques have been reported for the treatment of complete tendon rupture (Hirpara et al. 2007; Maquirriain 2011; Merolla et al. 2009; Rawson et al. 2013; Yildirim et al. 2006), but there is a lack of reliable suture methods for the ruptures that involve the muscle belly or MTJ (Faibisoff \& Daniel 1981; Kragh et al. 2005c; Oliva et al. 2013; Phillips \& Heggers 1988). Complete rupture at the MTJ is particularly difficult, whereas suture of the muscle belly has been previously 
80

81

attempted (Kragh et al. 2005a; Kragh et al. 2005b; Kragh et al. 2005c). The maintenance of the continuity in muscle-tendon unit is important, and strengthening of the adhesion properties is absolutely imperative, as there is a risk of repeated rupture after both surgical and/or non-surgical treatments (Kircher et al. 2010; Young et al. 2014).

Furthermore, tearing of the muscle-tendon unit can damage small blood vessels and nerves, generally causing local bleeding, pain, and/or paralysis. Therefore, the early re-establishment of peripheral nerve and blood vessels is important for the muscle repair process, in order to maintain the supply of $\mathrm{O}_{2}$ and other nutrients, and the removal of $\mathrm{CO}_{2}$ and other waste products (Ackermann et al. 2002; Ackermann et al. 2003; Nishimori et al. 2012). Additionally, it has been suggested that the repair of tendon ruptures can be stimulated by a single application of several growth factors, including platelet-derived growth factor (PDGF) (Hildebrand et al. 1998), transforming growth factor (TGF)- $\beta$ (Kashiwagi et al. 2004), insulin-like growth factor (IGF)-1 (Kurtz et al. 1999), basic-fibroblast growth factor (bFGF) (Chan et al. 2000), and vascular endothelial growth factor (VEGF) (Zhang et al. 2003). Synchronized supply of these factors is considered beneficial for the reconstruction of the muscle-tendon unit. Therefore, the application of an adhesive able to connect muscles to tendons may be a good treatment strategy for MTJ injury. Several scaffolds have been applied in the tendon healing treatments, and recent tissue-engineering investigations have shown that cell-scaffold constructs can improve the healing of tendon defects, compared with scaffolds alone (Ouyang et al. 2002; Ouyang et al. 2003; Young et al. 1998). Bone marrow-derived mesenchymal stem cells are most frequently applied as adjuvant cells, and their favorable healing effects have been reported (Chong et al. 2007; Harris et al. 
104

105

106

107

108

109

110

111

112

114

115

116

117

118

119

120

121

122

123

124

125

126

127

2004; Lu et al. 2016; Ouyang et al. 2004; Vieira et al. 2014), while the behavior of the transplanted cells, in terms of engraftment and differentiation, is poorly understood. An adipose-derived stem cell was also applied to the tendon repair, and a significant increase in tensile strength associate with the differentiation into tenocytes and endothelial cells were reported (Uysal \& Mizuno 2011). Similarly, skin-derived tenocyte-like cells was also used for the treatment of patellar tendinopathy, and greater improvement in pain and function was suggested (Clarke et al. 2011). However, these were applied to the tendon repair itself, thus, the effects for the MTJ rupture is still not clear.

We have determined that skeletal muscle-derived multipotent stem cells (Sk-MSCs) are capable of synchronized reconstitution of muscle-nerve-blood vessel unit and cellular differentiation into skeletal muscle cells, Schwann cells, perineurial/endoneurial cells, pericytes, vascular smooth muscle cells, and endothelial cells (Tamaki et al. 2007a; Tamaki et al. 2005). Recently, we developed a 3D gel-patch tissue reconstitution system using Sk-MSC sheet-pellets, which are able to preferentially reconstitute peripheral nerve and vascular tissues with robust connective tissue networks (Tamaki et al. 2013). Sk-MSC sheet-pellets also expressed various neurotropic/neurotrophic and vasculogenic factor mRNAs before and after transplantation (Soeda et al. 2013; Tamaki et al. 2013). These properties of Sk-MSCs and their sheet-pellets are considered to be beneficial for the reconstitution of muscle-tendon units, including their nerve-blood vessel networks. In this study, we developed a complete rupture model for MTJ in tibialis anterior (TA) muscle of mice, and applied Sk-MSC sheet-pellets as a "bio-bond"-like substance. Functional recovery, which was evaluated by the electrical stimulation-induced muscle contractions via the 
128

129

130

131

132

133

134

sciatic nerve, was measured and the behavior of engrafted cells was analyzed immunohistochemically. The putative paracrine capacity of growth factors in the sheet-pellets, relating to skeletal muscle, nerve, and vascular regeneration, was confirmed by RT-PCR and protein array.

\section{MATERIALS AND METHODS}

\section{Animals}

Green fluorescent protein transgenic mice (GFP-Tg mice; C57BL/6 TgN[act EGFP]Osb Y01, provided by Dr. M. Okabe, Osaka University, Osaka, Japan) (Okabe et al. 1997) were used as donor mice for the cell transplantation experiments (male, 4-8 week old, $n=6)$, and wild-type mice $(\mathrm{C} 57 \mathrm{BL} / 6 \mathrm{~N})$ were used as recipients (male, 8-12 week old, $n=26$ ). All experimental procedures were approved by the Tokai University School of Medicine Committee on Animal Care and Use (153015).

\section{Cell Purification and Preparation of Stem Cell Sheet-Pellets}

Sk-MSC sheet-pellets (Tamaki et al. 2013) were investigated for their effects on the regeneration of completely ruptured MTJ. Sheet-pellets generally showed gel-like characteristics (Fig. 1A), and they were able to be lifted using forceps (Fig. 1B). The thigh and lower leg muscles (tibialis anterior, extensor digitorum longus, soleus, plantaris, gastrocnemius, and quadriceps femoris) of GFP-Tg mice were removed and used in subsequent experiments. Muscle sampling was performed under an overdose of pentobarbital (60 mg/kg, Schering-Plough, combined with butorphanol tartrate $2 \mathrm{mg} / \mathrm{kg}$, Meiji Seika, Tokyo, Japan, i.p.). Average total muscle mass removed during the procedure was $512 \pm 67 \mathrm{mg} / \mathrm{GFP}-\mathrm{Tg}$ mouse (mean $\pm \mathrm{SE}$ ). Muscles were not minced, and 
152

153

154

155

156

157

158

159

160

161

162

163

164

were subsequently treated with $0.1 \%$ collagenase type IA (Sigma-Aldrich, Tokyo, Japan) in Dulbecco's modified Eagle's medium (DMEM, Wako, Osaka, Japan) containing 7.5\% fetal calf serum (FCS, Equitech Bio, TX, USA) with gentle agitation for $30 \mathrm{~min}$ at $37^{\circ} \mathrm{C}$. Following a short digestion, whole muscles were divided into fiber-bundles, which were washed with culture medium (Iscove's modified Dulbecco's medium; IMDM, Wako, Osaka, Japan) containing 10\% FCS, and cultured in IMDM/20\% FCS with 100 units/ml penicillin G, $100 \mu \mathrm{g} / \mathrm{ml}$ streptomycin sulfate (Wako, Osaka, Japan), $10 \mu \mathrm{g} / \mathrm{ml}$ gentamycin sulfate (Schering-Plough, Osaka, Japan), and 0.1 mM $\beta$-mercaptoethanol (Wako, Osaka, Japan) for 3 days. Cultured fiber-bundles associated with expanded cells were treated with trypsin-EDTA $(0.05 \%$ trypsin, 0.53 mM EDTA; Life Technologies, Tokyo, Japan), in order to dissociate individual cells. Single-cell suspension was filtered through 70-, 40- and 20- $\mu$ m nylon filters in order to remove muscle fibers and other debris, and, after washing, isolated cells were re-cultured in IMDM/20\% FCS for 2-3 days, until they reached confluence. In total, cells were expanded in culture for 5-6 days, which represents a reduced culture time compared with previous studies (Soeda et al. 2013; Tamaki et al. 2013), thus preserving the myogenic potential of sheet-pellets. After they reached confluence, the cells were gently detached from culture dishes using 2 mM EDTA solution. This step mainly affected $\mathrm{Ca}^{2+}$-dependent cell adhesion (e.g., cadherins), while cell-to-cell contact was maintained, sheet-like cell aggregations were collected and centrifuged, and stem cell sheet-pellets were obtained. Total sheet-pellet mass was $120 \pm 17 \mathrm{mg} / \mathrm{mouse}$ (mean $\pm \mathrm{SE}$ ), which means that over $100 \mathrm{mg}$ of sheet-pellets were obtained from about $500 \mathrm{mg}$ of skeletal muscle tissue. Throughout cell isolation, 7.5-10\% FCS was added to the collagenase and washing solutions in order to minimize contaminating protease activity 
176

177

178

179

180

181

182

and to protect isolated cells as much as possible.

\section{RT-PCR and protein Analysis of the Sheet-pellets}

Quality, differentiation potential and relative expressions of cytokines of the cells forming sheet-pellets was confirmed by RT-PCR and antibody array analysis immediately before the transplantation. Cells composed sheet-pellet was prepared for the RT-PCR, and their supernatant was prepared for antibody array analysis. For the RT-PCR analysis, specific primers and the analyzed materials are summarized in

Supplementary Table S1. Cells were lysed and total RNA was purified using a QIAGEN RNeasy Micro Kit (Hilden, Germany). First-strand cDNA synthesis was performed with Invitrogen SuperScript III system using dT30-containing primer (see

Supplementary Table S1), and specific PCR (35 cycles of $30 \mathrm{~s}$ at $94^{\circ} \mathrm{C}, 30 \mathrm{~s}$ at $60-65^{\circ} \mathrm{C}$ and 2 minutes at $72^{\circ} \mathrm{C}$ ) was performed in a $15-\mu 1$ volume containing Ex-Taq buffer, $0.8 \mathrm{U}$ of ExTaq-HS-polymerase, $0.7 \mu \mathrm{M}$ specific sense and antisense primers, $0.2 \mathrm{mM}$ dNTPs, and $0.5 \mu 1$ of cDNA. Relative expression was normalized to the expression of a housekeeping control (HPRT). Details of this analysis were described previously (Tamaki et al. 2013).

Concurrently, several cytokines, which are related to the muscular and vascular regeneration were also analyzed by antibody array kit (Proteome Profiler, ARY013, R \& D Systems, Minneapolis, MN), as a protein level. Cell culture supernatant of sheet-pellet just before the transplantation was obtained after removal of particulates by centrifugation, and 500- $\mu 1$ of supernates was prepared for the analysis. Culture medium containing $20 \%$ FCS was also prepared for the same analysis in order to check the background effects. The relative expression levels of several cytokines; such as 
200

201

202

203

204

205

206

207

208

209

210

211

212

213

214

215

216

217

218

219

220

221

222

223

interleukin-6 (IL-6), insulin-like growth factor-1 and 2 (IGF-1 and 2) and their related proteins IGF binding protein-1, 2, 5, and 6 (IGFBP-1, 2, 5 and 6), which are the critical regulator of myogenesis; a regulator/enhancer of macrophage such as chemokine (C-C motif) ligand 2 (MCP-1) and colony stimulating factor 1 (M-CSF); a regulator/activator of wide range of cell types such as fibroblast growth factor-21 (FGF-21) and tissue inhibitor of metalloproteinase 1 (TIMP-1); and vascular endothelial growth factor (VEGF) were determined.

\section{Complete Rupture of MTJ Model and Application of Sheet-Pellets}

In order to prepare the experimental complete rupture model, we manually detached muscle fibers from the distal tendons of the right tibialis anterior (TA) muscles of recipient mice $(n=19)$. All surgical preparations were performed under the inhalation anesthesia (Isoflurane; Abbot, Osaka, Japan). A summary of the procedure is shown in

Figure 1. First, TA muscle was exposed (C, step 1), and muscle fibers were subsequently detached from the distal tendon and peeled off using cotton swabs for one half of the entire TA length (D, step 2), and everted necrotic fiber portions were removed (step 3). The average removed muscle mass was $21.5 \pm 1.8 \mathrm{~g}$, and this represented about $40 \%$ of total muscle mass. Sheet-pellets were then adhered to the open region of completely ruptured MTJ (Fig. 1E, step 4; Sheet-pellet, SP group, n=14), and skin was sutured (E, white arrows). The left side was preserved as a contralateral control. The non-transplanted control group ( $\mathrm{C}$ group, $\mathrm{n}=10)$ underwent the same surgery, and the same amount of cell-free culture medium was administered. The mice were allowed full freedom of movement after surgery. 
224

225

226

227

\section{Functional Assessment of the Regenerated TA Muscles}

After the transplantation, the animals were divided into two groups as short-term (4-8 weeks) and long-term (14-18 weeks) recoveries, and prepared for the functional assessment. The first assessment was begun at 4 weeks using each one mouse in $\mathrm{SP}$ and $\mathrm{C}$ group, and tetanic tension outputs of regenerated TA muscles were measured in both left (non-operated control side) and right (operated side) legs. The tetanic tension output was considered as the total functional recovery of the operated TA muscle, and recovery ratio was determined based on the contralateral non-operated control side. Following assessments were performed every week (0.5-1.5 week interval) during each group terms using one by one mouse, then, SP and C groups were compared. Measurements were performed in situ under inhalation anesthesia (Isoflurane; Abbot, Osaka, Japan), and body (rectal) temperature was maintained at $36 \pm 1^{\circ} \mathrm{C}$ with a radiant heat light throughout the measurement. Details of this measurement were as described previously (Tamaki et al. 2005). Briefly, the distal tendon of TA muscle and sciatic nerve (about $10 \mathrm{~mm}$ ) on both sides were carefully exposed, and tissues were coated with mineral oil to prevent tissue drying and to minimize electrical noise interference. A bipolar silver $(\mathrm{Ag} / \mathrm{Ag}$ ) electrode (inter-electrode distance: $2 \mathrm{~mm}$ ) was placed under the sciatic nerve. A stainless steel hook was attached to the distal tendon of each TA muscle using a silk ligature. The animal was transferred to a custom-made operating table that allowed stabilization of the head and limbs in a supine position using surgical tape. A stainless steel hook was attached to a force-distance transducer (FD-Pickup, TB-611T; Nihon Kohden, Tokyo, Japan) connected to the carrier amplifier (AP-621G; Nihon Kohden). This enabled the measurements of the muscle contraction force and its distance to be conducted. A bipolar silver electrode (inter-electrode distance: $5 \mathrm{~mm} / 1$ 
248

249

250

251

253

254

255

256

258

259

260

261

mm diameter) was attached to the surface of the reference muscle as well, in order to obtain an evoked electrical myogram, as a confirmation of stable muscle contractions. We have taken care to avoid interference of the reference muscle and nerves with the normal blood supply. Afterward, twitches were elicited by single pulse (1 ms duration, $0.5 \mathrm{~Hz}$ ) electrical stimulation via the sciatic nerve, at a voltage above the threshold for a maximum response (1.5-4.0 V). Subsequently, peak tetanic tension was determined using stimulation frequencies of 10, 20, 40,60, 80, 100, 120, and $140 \mathrm{~Hz}$ of $0.5 \mathrm{~s}$ duration at $15 \mathrm{~s}$ intervals. The frequency that produced the highest tetanic tension was considered the optimal stimulation for tetanus. All mechanical and electrical measurements were recorded on a Linearcorder (Mark VII, WR3101; Graphtec, Tokyo, Japan) as analog data.

\section{Macroscopic Observation and Immunostaining}

Following the functional measurements above, recipient mice (including the animals used for morphological analysis only, 5-10 weeks after transplantation, $\mathrm{n}=5$ ) were given an overdose of pentobarbital $(60 \mathrm{mg} / \mathrm{kg}$, combined with butorphanol tartrate $2 \mathrm{mg} / \mathrm{kg}$, i.p.), and the engraftment of donor-derived $\mathrm{GFP}^{+}$cells into the damaged portion of TA muscle was confirmed by fluorescence stereomicroscopy (SZX12; Olympus, Tokyo, Japan, Figure 4). Recipient mice were perfused with warm $0.01 \mathrm{M}$ phosphate-buffered saline (PBS, Wako, Osaka, Japan) through the left ventricle, followed by fixation with $4 \%$ paraformaldehyde $/ 0.1 \mathrm{M}$ phosphate buffer (4\% PFA/PB, Wako, Osaka, Japan). Muscles were removed and fixed overnight in 4\% PFA/PB, washed with graded sucrose (0-25\%, Wako, Osaka, Japan)/0.01 M PBS series, and quick frozen with isopentane (Wako, Osaka, Japan) pre-cooled by liquid nitrogen, 
272

273

274

275

276

277

278

279

280

281

282

283

284

285

286

287

288

289

290

291

292

293

294

295

followed by storage at $-80^{\circ} \mathrm{C}$. Subsequently, $7 \mu \mathrm{m}$ cross-sections were obtained.

Skeletal muscle fibers were stained with anti-skeletal muscle actin ( $\alpha$ SkMA; dilution, 1:200; incubation, room temperature for $2 \mathrm{~h}$; Abcam, Cambridge, UK). Nerve fiber localization (axons) was detected by rabbit polyclonal anti-Neurofilament 200 (N-200, dilution, 1:1000; incubation, room temperature for $1 \mathrm{~h}$; Sigma, St. Louis, MO, USA).

Schwann cells were detected using anti-p75 (rabbit polyclonal, 1:400, $4^{\circ} \mathrm{C}$ overnight; CST, Boston, MA, USA). Blood vessels were detected with rat anti-mouse CD31 (1:500, $4^{\circ} \mathrm{C}$ overnight; BD Pharmingen, San Diego, CA, USA) monoclonal antibody, which is a known vascular endothelial cell marker, and mouse monoclonal $\alpha$-smooth muscle actin ( $\alpha$ SMA, Cy3-conjugated; 1:1500; room temperature for $1 \mathrm{~h}$; Sigma, St. Louis, MO, USA). Dystrophin formation in the skeletal muscle fibers was detected using goat anti-dystrophin polyclonal antibody $\left(1: 50,4^{\circ} \mathrm{C}\right.$, overnight; Santa Cruz Biotechnology, Dallas, TX, USA). Neuromuscular junctions were detected by a-bungarotoxin (Alexa Fluor 594 conjugated, 1:100, room temperature,1 h; Molecular Probes, Eugene, OR, USA). Reactions were visualized using Alexa Fluor-594-conjugated goat anti-rabbit and anti-rat antibodies (1:500, room temperature, 2 h; Molecular Probes, Eugene, OR, USA). Nuclei were counter-stained with DAPI (4,6-diamino-2-phenylindole).

\section{Statistical Analysis}

Differences between two groups (short and long term recovery group) were tested using Student's t test, and the significance level was set at $\mathrm{p}<0.05$. Values are expressed as mean $\pm \mathrm{SE}$. 
297

298

299

300

301

302

303

304

305

306

307

308

309

310

311

312

313

314

315

316

317

318

319

\section{RESULTS}

\section{Quality and Therapeutic Potential of Sk-MSC Sheet-pellets}

Quality, differentiation, and putative therapeutic potential of the sheet-pellet were first confirmed by RT-PCR and protein array analysis (Figure 2). The expression of specific myogenic, neurotrophic, and vasculogenic factor mRNAs in the sheet-pellets immediately before the transplantation is shown in Figure 2A. The Sk-MSC sheet-pellets showed expressions of various myogenic factors (MyoD, Myf5, Pax7, Myogenin, c-met, Mcad, MyH, Desmin, and IGF-1), neurotrophic factors (NGF, BDNF, GDNF, CNTF, LIF, Ninjurin, Galectin, Nestin, and Sox10) and vascular growth factors (VEGF, HGF, PDGF, TGF- $\beta$, EGF, and FGFb), except Pax3. These results agree with a previous report (Tamaki et al. 2013), which showed good quality of this method of sheet-pellet preparation.

In addition, relative increase in the expressions of proteins (cytokines) was also detected in the same sheet-pellet culture supernatant (Figure 2B). An increase of myokine (Munoz-Canoves et al. 2013; Pedersen 2012), which is a critical regulator of muscle regeneration, such as IL-6 and IGF-1 and 2 associate with their relating IGFBP-2, 3, 5 and 6, the chemokine, which is an up-regulator of monocyte/macrophage (MCP-1 and M-CSF) in the tissue regeneration (Pantsulaia et al. 2005; Shiba et al. 2007), and a regulator/activator of a wide range of cell types (FGF-21 and TIMP-1) (Mas et al. 2007; Wan 2013) was detected, showing a paracrine capacity of the sheet-pellet.

\section{Functional Recovery}


differences between the short-term and the long-term recovery group, with these

SP short term recovery group showed about $64 \%$ recovery of muscle mass, and about $28 \%$ recovery of tetanic tension output relative to the contralateral side (Fig. 3A, B). Then, the SP long term recovery group showed increased recovery of average muscle mass (77\%), and significant recovery of tetanic tension output (49\%, Fig. 3A, B). week (Fig. 3A) with strong atrophy coalescence into the tibial bone (see next Fig. 4I, J and $\mathbf{K}$ ), and incomplete recover of the muscle-tendon unit continuity. This atrophy apparently progressed toward 6 weeks (compare I and J). Thus, it was clear that this model is irreversible spontaneously. Therefore, we were unable to continue measuring muscle mass and tension output in the media Control group subsequently. Average recovery ratio of muscle mass gradually increased in the long-term group, and the tetanic tension showed significantly higher recovery (Fig. 3A and B), showing that a development of recoveries continued/progressed over 14 weeks after operation. When the recoveries were analyzed individually in each group separately, a linear relationship as the term depends manner of recoveries was observed relatively because general activities (go around, hanging and downside walking of cage lid) by our animal care observations. 


\section{Macroscopic Examination}

Typical fluorescence macroscopic features at 4-10 weeks after the engraftment of transplanted $\mathrm{GFP}^{+}$sheet-pellets are shown in Figure 4. In situ observation revealed that a large volume of $\mathrm{GFP}^{+}$tissues was engrafted in the damaged TA muscle portion after transplantation, and these tissues showed 5 different patterns. Pattern 1 was the most common one (5/13 samples), showing broad and thick engraftment through the tendon to the mid portion of the muscle (Figs. 4A-C). GFP ${ }^{+}$engrafted tissue was observed in blood vessel networks (arrows in Fig. 4B), and the continuity was clearly maintained (Fig. 4C). This pattern was mainly composed of connective tissue with few muscle fibers. Pattern 2 was rarely observed (1/13 samples), and it mostly comprised of the muscle fibers (Fig. 4D) that extended from the mid portion of MTJ to the upper portion, and with few connective tissues. Pattern 3 (1/13 samples) in contrast, mainly comprised of the connective tissue at the distal portion of MTJ, with few muscle fibers (Fig. 4E). Patterns 4 (3/13 samples) and 5 (3/13 samples) were mixed types, showing both muscle fibers and connective tissues (Figs. 4F-H), but GFP was relatively sparse, and the amount of connective tissues was small in Pattern 4 (Fig. 4F), while Pattern 5 showed even distribution of both tissues (Fig. 4G). Active blood vessels in and around $\mathrm{GFP}^{+}$tissues were equally observed in all Patterns (arrows in Figs. 4B, and 4D-4H). Severe atrophy of TA muscle was generally observed in the C group (Figs. 4I and 4J), and this pattern was observed in $7 / 7$ control mice. On the lateral side of the tibia (black arrows in Figs. 4I and 4J), a portion of the TA muscle was clearly hollowed (white arrows in Fig. 4I), and there were no muscle fibers present. Apparent adipose tissue formation (red arrows in Fig. 4J) was also observed, suggesting lack or very weak continuity of the TA muscle-tendon unit (Fig. 4J). An apparent muscle deficit of 
distal-half of operated TA with a meager tendon was confirmed in the isolated TA muscle of $\mathrm{C}$ group $(\mathrm{K})$, suggesting the difficulty of force generation. Progressive muscle atrophy of the remaining proximal-half portion of TA was also apparent (compare I and $\mathrm{J}$ in dotted circles).

\section{Immunohistochemical Analysis of the Engrafted Cells}

At 4-10 weeks following the surgery, the behavior of engrafted $\mathrm{GFP}^{+}$cells was analyzed in cross-sections. Figure 5 shows the result of Pattern 1. Thick tissues composed of $\mathrm{GFP}^{+}$cells closely adhered to skeletal muscle fibers (Fig. 5A). $\mathrm{GFP}^{+}$cells surrounded the tendon, and van Gieson elastic fiber staining showed connective tissue networks (Fig. 5B). This suggests that the engrafted $\mathrm{GFP}^{+}$tissue formed connective tissue networks, which connected both the tendon and the muscle fibers, displaying a "bio-bond" role. Additionally, invagination of $\mathrm{GFP}^{+}$cell-derived connective tissue was observed in the tendon (yellow arrows in Fig. 5C), and showed differentiation into vascular endothelial cells (CD31 + GFP, white arrows in 5C). A similar trend was also observed on the muscle fiber side, and the migration of $\mathrm{GFP}^{+}$cells could be seen between muscle fibers (Fig. 5D, below the dotted line). A close relationship (not double staining) of $\mathrm{N}^{200^{+}}$nerve axons and $\mathrm{GFP}^{+}$cells, was observed on both the muscle side (below the dotted line) and the connective tissue side (Fig. 5D, upper-side of dotted line). $\mathrm{GFP}^{+}$cells in the connective tissue were positive for p75 (Fig. 5E, right side of dotted line) and therefore, they were considered Schwann cells. These results support a close relationship between $\mathrm{GFP}^{+}$cells and nerve axons, which is detectable in Figure 5D. The relationship among engrafted $\mathrm{GFP}^{+}$connective tissue, tendon, and muscle fibers is more apparent in Figure 4F. GFP ${ }^{+}$connective tissue bridging tendon (T) and 
392

393

394

396

397

398

399

400

401

402

403

404

405

406

407

408

409

410

411

412

413

414

415

muscle fibers (right side of the panel) expressed dystrophin (red), which suggests a strong relationship between connective tissue and muscle fibers through dystrophin complexes.

Similarly, longitudinal profiles obtained from pattern 5 are shown in Figure 6. Engrafted $\mathrm{GFP}^{+}$cell-derived connective tissues closely adhered to the muscle fibers (Fig. 6A), and $\mathrm{GFP}^{+}$muscle fibers were also observed (Fig. 6B). Differentiation of $\mathrm{GFP}^{+}$cells into vascular smooth muscle cells was seen in the connective tissue network (Fig. 6C, arrows, double staining with GFP+SMA), contributing to a relatively large blood vessel formation. The involvement in the peripheral nerve reconstitution was indicated by a close relationship between $\mathrm{GFP}^{+}$cells and axons (Fig. 6D, arrows, close distributions of $\mathrm{GFP}^{+}$cells and $\mathrm{N} 200^{+}$axons). This relationship was supported by the differentiation of $\mathrm{GFP}^{+}$cells into Schwann cells positive for p75 (Fig. 6E, arrows, double staining of GFP+p75). Similarly, a close relationship of $\mathrm{GFP}^{+}$cells and muscle fibers, nerve axons, and the neuromuscular junctions was evident (Fig. 6F, in the dotted line circle as $\alpha$-bungarotoxin ${ }^{+}$), confirming that $\mathrm{GFP}^{+}$cells contributed to peripheral nerve extensions, reaching to the end of a motor nerve. These results indicate that the transplanted $\mathrm{GFP}^{+}$Sk-MSC sheet-pellets mainly form connective tissue networks together with a certain amount of muscle fibers, and that they physically bind the tendon and muscle fibers, contributing to the peripheral nerve-blood vessel formation.

\section{DISCUSSION}

Injuries involving the muscle belly or MTJ are challenging for surgeons because the muscle tissue shows poor suture-holding capacity, and the reliable suture 
416

417

418

419

420

421

422

methods have not been established yet (Faibisoff \& Daniel 1981; Kragh et al. 2005c;

Oliva et al. 2013; Phillips \& Heggers 1988). However, reconstruction and/or re-establishment of continuity in the muscle-tendon unit is vital for the functional repair, because of the primary role of muscle force generation and transmission. We have investigated the reconstruction of completely ruptured TA muscle at the MTJ, using Sk-MSC sheet-pellets as "bio-bonds." The results indicate that Sk-MSC sheet-pellet transplantation achieved favorable results in the reconstruction and/or reconnection of the ruptured muscles and tendons. Engrafted Sk-MSCs primarily formed connective tissues, including neurovascular networks, and bridged both the tendon and muscle fibers, with differentiation into skeletal muscle fibers, Schwann cells, vascular smooth muscles, and endothelial cells. The differentiation capacity of these cells was previously predicted, since the present sheet-pellet was mainly composed of the mixed population of multipotent Sk-34 (CD34+/45) (Tamaki et al. 2002; Tamaki et al. 2005) and Sk-DN (CD34/45') (Tamaki et al. 2003; Tamaki et al. 2007a; Tamaki et al. 2007b) cells, and their putative potential for the therapy was confirmed by RT-PCR and protein array analysis immediately before the transplantation (Fig. 2A and B). Furthermore, the migration of engrafted $\mathrm{GFP}^{+}$fibroblast-like cells was observed around the tendon and the interstitium of muscle fibers, mechanically bridging the tendon-muscle gap. This reconnecting behavior is considered the "bio-bond" activity. Establishment of a muscle fiber holding capacity in donor-derived connective tissue was further suggested by the expression of dystrophin in MTJ fibers (Fig. 5F), because of the role of dystrophin-dystroglycan $(\alpha, \beta)$ complex in the collagen network (Monti et al. 1999; Welser et al. 2009). In our previous studies, we prepared the sheet-pellets as the accelerators of the neurovascular reconstitution with diminished myogenic potential 
440 (Soeda et al. 2013; Tamaki et al. 2013). Here, we used a shorter term expansion culture

441 (in particular, the term of first fiber culture), and this shorter culture period helped

442 preserve the myogenic potential of the sheet-pellets, resulting in new myofiber

443 formation. This was confirmed by the comparison of the RT-PCR data obtained in the previous studies (Soeda et al. 2013; Tamaki et al. 2013) and the results obtained in this one (Fig. 2). The relatively preserved myofiber formation capacity may have also contributed to the enhanced connection of the muscle-tendon unit. disrupted TA muscles by $36 \%$ in the short term recovery group, and this increased $49 \%$ in the long term recovery group. Concerning to the relationship between the engrafted patterns (Fig. 4) and functions, relatively higher contractions were dominantly observed in the Pattern 4 and 5 (Fig. 4F and $\mathbf{G}$ ), which showed mixed types of GFP engraftment of both muscle fibers and connective tissues. The tension recoveries were further supported by the immunohistochemical staining results, showing that $\mathrm{GFP}^{+}$cells contributed to motor nerve extensions, close to the neuromuscular junctions (Fig. 6F, from Pattern 5). We did not perform the tensile strength test of the regenerated muscles, but no muscle ruptures were observed during repetitive maximum tetanic tension measurements. In addition, the absolute value of the tension output of operated-muscles rehabilitation, which resulted in an increased tension recovery in the long term group

(Table 1 and Fig. 3A, B). The notion of this rehabilitation (increased body activity) depends increase in the tension recovery was further suggested by the term dependent 
464

465

466

467

468

469

linear relationship, as was observed particularly in the individual plots of the long term group (Fig. 3D). Because we observed enhanced general cage activities of the mice in the long term group compared to the short term group, and the same trend was also detected clearly in the muscle mass recovery (Fig. 3C). Thus, we believe that this linear relationship may be due to an increased general activity of mice day by day following the improvement in the general symptoms, such as reduced pain and uncomfortable feeling. In this regard, it was suggested that these symptoms were more prominent in the short term group, and may induce lower activities. However, this lower activity might be a benefit for tissue recovery by contraries. By these reasons, it was also suggested that an earlier start of positive rehabilitation, probably around 8 weeks after operation, may have more rapid and enhanced recovery of this therapy was expected.

As a consequence, the non-transplanted control group did not achieve sufficient reconnection of muscle-tendon units (Fig. 4 and Table 1), showing that the MTJ rupture model we used is an irreversible model. It has been reported that the early reconnection induced mechanical stimulation is effective for the repair and quality maintenance of the tendon, because the lack of this stimulation produced detrimental effects (Lin et al. 2004; Matsumoto et al. 2003). Therefore, we concluded that the absence of mechanical-tension in the control group, after the complete removal of the MTJ, may have caused a massive muscle atrophy associated with the fatty tissue replacement (Fig. 4). It is also a fact that the present sheet-pellets transplantation prevented this detrimental effects.

Additionally, it has been suggested that early peripheral nerve regeneration and the provision of neuropeptides are important for the healing of normal connective tissue and tendon (Ackermann et al. 2002; Ackermann et al. 2003). Neovascularization plays a 
488

489

490

491

492

493

494

495

496

497

498

499

500

501

502

503

504

505

506

507

508

509

510

511

critical role in the healing process of the ligament (Nishimori et al. 2012). The repair of angiokinesis (vasodilation-constriction) through the neurovascular regeneration is also important for tissue regeneration (Ackermann et al. 2002). Our treatment meets all these conditions. Previous studies demonstrated that Sk-MSCs transplantation facilitates/accelerates nerve-vascular formation (Tamaki et al. 2014; Tamaki et al. 2007a; Tamaki et al. 2013; Tamaki et al. 2005). The expressions of various nerve-blood vessel-related growth and trophic factors before and after transplantation was also observed in the case of nerve-gap regeneration (Tamaki et al. 2014). In our study, prolonged expression of these genes, shown in Figure 2, was expected and observed following the transplantation, and it may be beneficial for the healing of muscle-tendon units.

We recently established a practical/therapeutic method of isolation of human skeletal muscle-derived stem cells (Tamaki et al. 2015). Using this method, we found that human cells can be divided into 2 stem/progenitor cell fractions; 1 ) the cells showing preferential differentiation into the skeletal myogenic lineage $\left(\mathrm{CD} 45^{\circ} / \mathrm{CD} 34^{-} / 29^{+}=\mathrm{Sk}-\mathrm{DN} / 29^{+}\right)$, and 2$)$ cells showing multiple differentiation into nerve-blood vessel cell lineages $\left(\mathrm{CD} 45^{1} / 34^{+}=\mathrm{Sk}-34\right)$. The combined differentiation/reconstitution capacities of these cells after in vivo transplantation were comparable to the mouse Sk-MSCs (Tamaki et al. 2015). Therefore, the cell fractions could be selected and adjusted for the treatment of muscle fibers, nerve-blood vessels associated with connective tissues, or both. Additionally, these stem/progenitor cells can be obtained from various muscle regions, including the legs and abdominals (Tamaki et al. 2015). The removal of a small sample (around $3 \mathrm{~g}$ ) from the lower abdominal wall muscle carries low risk to the loss of motor function.

Peerj reviewing PDF | (2016:01:8686:2:1:NEW 16 Jun 2016) 


\section{CONCLUSIONS}

In the present study, we successfully demonstrated that Sk-MSC sheet-pellet

515

516

517

518

transplantation can bridge complete rupture of MTJ, and form connective tissue networks associated with cellular differentiation into skeletal muscle fibers, Schwann cells, vascular smooth muscle, and endothelial cells. These connective tissues migrated around the tendon and muscle fiber interstitium and connected both tissues, playing a role of a "bio-bond." Paracrine effects of nerve and vascular growth factors, as well as trophic factors, produced by Sk-MSCs may also be beneficial for the reparation of the tissue. Together with the recent establishment of human skeletal muscle-derived cells, Sk-MSCs may be an optimal autologous cell source, used as an adjuvant, which would lead to a promising therapy for muscle-tendon injuries. Furthermore, the combined therapies, such as an appropriate suture with sheet-pellet, or suture together with sheet-pellet and scaffold use, may also represent favorable therapies for the MTJ rupture repair, particularly because of the higher tensile strength required in humans.

\section{REFERENCES}

Ackermann PW, Ahmed M, and Kreicbergs A. 2002. Early nerve regeneration after achilles tendon rupture--a prerequisite for healing? A study in the rat. J Orthop Res 20:849-856. 10.1016/S0736-0266(01)00159-0

Ackermann PW, Li J, Lundeberg T, and Kreicbergs A. 2003. Neuronal plasticity in relation to nociception and healing of rat achilles tendon. J Orthop Res 21:432-441. 10.1016/S0736-0266(02)00207-3

Chan BP, Fu S, Qin L, Lee K, Rolf CG, and Chan K. 2000. Effects of basic fibroblast growth factor (bFGF) on early stages of tendon healing: a rat patellar tendon model. Acta Orthop Scand 71:513-518. 10.1080/000164700317381234

Chan O, Del Buono A, Best TM, and Maffulli N. 2012. Acute muscle strain injuries: a proposed new classification system. Knee Surg Sports Traumatol Arthrosc 
20:2356-2362. 10.1007/s00167-012-2118-z

Chong AK, Ang AD, Goh JC, Hui JH, Lim AY, Lee EH, and Lim BH. 2007. Bone marrow-derived mesenchymal stem cells influence early tendon-healing in a rabbit achilles tendon model. $J$ Bone Joint Surg Am 89:74-81. 10.2106/JBJS.E.01396

Clarke AW, Alyas F, Morris T, Robertson CJ, Bell J, and Connell DA. 2011. Skin-derived tenocyte-like cells for the treatment of patellar tendinopathy. Am J Sports Med 39:614-623. 10.1177/0363546510387095

ElMaraghy AW, and Devereaux MW. 2012. A systematic review and comprehensive classification of pectoralis major tears. J Shoulder Elbow Surg 21:412-422. 10.1016/j.jse.2011.04.035

Faibisoff B, and Daniel RK. 1981. Management of severe forearm injuries. Surg Clin North Am 61:287-301.

Harris MT, Butler DL, Boivin GP, Florer JB, Schantz EJ, and Wenstrup RJ. 2004. Mesenchymal stem cells used for rabbit tendon repair can form ectopic bone and express alkaline phosphatase activity in constructs. J Orthop Res 22:998-1003. 10.1016/j.orthres.2004.02.012

Hildebrand KA, Woo SL, Smith DW, Allen CR, Deie M, Taylor BJ, and Schmidt CC. 1998. The effects of platelet-derived growth factor-BB on healing of the rabbit medial collateral ligament. An in vivo study. Am J Sports Med 26:549-554.

Hirpara KM, Sullivan PJ, Raheem O, and O'Sullivan ME. 2007. A biomechanical analysis of multistrand repairs with the Silfverskiold peripheral cross-stitch. $J$ Bone Joint Surg Br 89:1396-1401. 10.1302/0301-620X.89B10.19360

Kashiwagi K, Mochizuki Y, Yasunaga Y, Ishida O, Deie M, and Ochi M. 2004. Effects of transforming growth factor-beta 1 on the early stages of healing of the Achilles tendon in a rat model. Scand J Plast Reconstr Surg Hand Surg 38:193-197. 10.1080/02844310410029110

Kircher J, Ziskoven C, Patzer T, Zaps D, Bittersohl B, and Krauspe R. 2010. Surgical and nonsurgical treatment of total rupture of the pectoralis major muscle in athletes: update and critical appraisal. Open Access J Sports Med 1:201-205. 10.2147/OAJSM.S9066

Kragh JF, Jr., Svoboda SJ, Wenke JC, Brooks DE, Bice TG, and Walters TJ. 2005a. The role of epimysium in suturing skeletal muscle lacerations. J Am Coll Surg 200:38-44. 10.1016/j.jamcollsurg.2004.09.009

Kragh JF, Jr., Svoboda SJ, Wenke JC, Ward JA, and Walters TJ. 2005b. Epimysium and perimysium in suturing in skeletal muscle lacerations. J Trauma 59:209-212. 
576

577

578

579

580

581

582

583

584

585

586

587

588

589

590

591

592

593

594

595

596

597

598

599

600

601

602

603

604

605

606

607

608

609

610

611

Kragh JF, Jr., Svoboda SJ, Wenke JC, Ward JA, and Walters TJ. 2005c. Suturing of lacerations of skeletal muscle. $J$ Bone Joint Surg $\mathrm{Br}$ 87:1303-1305. 10.1302/0301-620X.87B9.15728

Kurtz CA, Loebig TG, Anderson DD, DeMeo PJ, and Campbell PG. 1999. Insulin-like growth factor I accelerates functional recovery from Achilles tendon injury in a rat model. Am J Sports Med 27:363-369.

Lin TW, Cardenas L, and Soslowsky LJ. 2004. Biomechanics of tendon injury and repair. J Biomech 37:865-877. 10.1016/j.jbiomech.2003.11.005

Lu YF, Chan KM, Li G, and Zhang JF. 2016. Tenogenic differentiation of mesenchymal stem cells and noncoding RNA: From bench to bedside. Exp Cell Res 341:237-242. 10.1016/j.yexcr.2015.12.014

Maquirriain J. 2011. Achilles tendon rupture: avoiding tendon lengthening during surgical repair and rehabilitation. Yale J Biol Med 84:289-300.

Mas VR, Maluf DG, Archer KJ, Yanek KC, and Fisher RA. 2007. Angiogenesis soluble factors as hepatocellular carcinoma noninvasive markers for monitoring hepatitis C virus cirrhotic patients awaiting liver transplantation. Transplantation 84:1262-1271. 10.1097/01.tp.0000287596.91520.1a

Matsumoto F, Trudel G, Uhthoff HK, and Backman DS. 2003. Mechanical effects of immobilization on the Achilles' tendon. Arch Phys Med Rehabil 84:662-667.

Merolla G, Campi F, Paladini P, and Porcellini G. 2009. Surgical approach to acute pectoralis major tendon rupture. G Chir 30:53-57.

Monti RJ, Roy RR, Hodgson JA, and Edgerton VR. 1999. Transmission of forces within mammalian skeletal muscles. J Biomech 32:371-380.

Munoz-Canoves P, Scheele C, Pedersen BK, and Serrano AL. 2013. Interleukin-6 myokine signaling in skeletal muscle: a double-edged sword? FEBS J 280:4131-4148. 10.1111/febs.12338

Nishimori M, Matsumoto T, Ota S, Kopf S, Mifune Y, Harner C, Ochi M, Fu FH, and Huard J. 2012. Role of angiogenesis after muscle derived stem cell transplantation in injured medial collateral ligament. J Orthop Res 30:627-633. 10.1002/jor.21551

Okabe M, Ikawa M, Kominami K, Nakanishi T, and Nishimune Y. 1997. 'Green mice' as a source of ubiquitous green cells. FEBS Lett 407:313-319. S0014-5793(97)00313-X [pii]

Oliva F, Via AG, Kiritsi O, Foti C, and Maffulli N. 2013. Surgical repair of muscle laceration: biomechanical properties at 6 years follow-up. Muscles Ligaments Tendons J 3:313-317. 
612 Ouyang HW, Goh JC, and Lee EH. 2004. Use of bone marrow stromal cells for tendon

613

614

615

616

617

618

619

620

621

622

623

624

625

626

627

628

629

630

631

632

633

634

635

636

637

638

639

640

641

642

643

644

645

646

647 graft-to-bone healing: histological and immunohistochemical studies in a rabbit model. Am J Sports Med 32:321-327.

Ouyang HW, Goh JC, Mo XM, Teoh SH, and Lee EH. 2002. The efficacy of bone marrow stromal cell-seeded knitted PLGA fiber scaffold for Achilles tendon repair. Ann N Y Acad Sci 961:126-129.

Ouyang HW, Goh JC, Thambyah A, Teoh SH, and Lee EH. 2003. Knitted poly-lactide-co-glycolide scaffold loaded with bone marrow stromal cells in repair and regeneration of rabbit Achilles tendon. Tissue Eng 9:431-439. $10.1089 / 107632703322066615$

Pantsulaia I, Trofimov S, Kobyliansky E, and Livshits G. 2005. Contribution of the familial and genetic factors on monocyte chemoattractant protein-1 variation in healthy human pedigrees. Cytokine 32:117-123. 10.1016/j.cyto.2005.08.006

Pedersen BK. 2012. Muscular interleukin-6 and its role as an energy sensor. Med Sci Sports Exerc 44:392-396. 10.1249/MSS.0b013e31822f94ac

Phillips LG, and Heggers JP. 1988. Layered closure of lacerations. Postgrad Med 83:142-148.

Rawson S, Cartmell S, and Wong J. 2013. Suture techniques for tendon repair; a comparative review. Muscles Ligaments Tendons J 3:220-228.

Shiba Y, Takahashi M, Yoshioka T, Yajima N, Morimoto H, Izawa A, Ise H, Hatake K, Motoyoshi K, and Ikeda U. 2007. M-CSF accelerates neointimal formation in the early phase after vascular injury in mice: the critical role of the SDF-1-CXCR4 system. Arterioscler Thromb Vasc Biol 27:283-289. 10.1161/01.ATV.0000250606.70669.14

Soeda S, Tamaki T, Hashimoto H, Saito K, Sakai A, Nakajima N, Nakazato K, Masuda M, and Terachi T. 2013. Functional Nerve-Vascular Reconstitution of the Bladder-Wall; Application of Patch Transplantation of Skeletal Muscle-Derived Multipotent Stem Cell Sheet-Pellets. J Stem Cell Res Ther 3:142.

Tamaki T, Akatsuka A, Ando K, Nakamura Y, Matsuzawa H, Hotta T, Roy RR, and Edgerton VR. 2002. Identification of myogenic-endothelial progenitor cells in the interstitial spaces of skeletal muscle. J Cell Biol 157:571-577.

Tamaki T, Akatsuka A, Okada Y, Matsuzaki Y, Okano H, and Kimura M. 2003. Growth and differentiation potential of main- and side-population cells derived from murine skeletal muscle. Exp Cell Res 291:83-90.

Tamaki T, Hirata M, Soeda S, Nakajima N, Saito K, Nakazato K, Okada Y, Hashimoto H, Uchiyama Y, and Mochida J. 2014. Preferential and comprehensive 
648

649

650

651

652

653

654

655

656

657

658

659

660

661

662

663

664

665

666

667

668

669

670

671

672

673

674

675

676

677

678

679

680

681

682

683

reconstitution of severely damaged sciatic nerve using murine skeletal muscle-derived multipotent stem cells. PLoS One 9:e91257. 10.1371/journal.pone.0091257

PONE-D-13-38421 [pii]

Tamaki T, Okada Y, Uchiyama Y, Tono K, Masuda M, Wada M, Hoshi A, and Akatsuka A. 2007a. Synchronized reconstitution of muscle fibers, peripheral nerves and blood vessels by murine skeletal muscle-derived CD34(-)/45 (-) cells. Histochem Cell Biol 128:349-360. 10.1007/s00418-007-0331-5

Tamaki T, Okada Y, Uchiyama Y, Tono K, Masuda M, Wada M, Hoshi A, Ishikawa T, and Akatsuka A. 2007b. Clonal multipotency of skeletal muscle-derived stem cells between mesodermal and ectodermal lineage. Stem Cells 25:2283-2290. 2006-0746 [pii]

10.1634/stemcells.2006-0746

Tamaki T, Soeda S, Hashimoto H, Saito K, Sakai A, Nakajima N, Masuda M, Fukunishi N, Uchiyama Y, Terachi T, and Mochida J. 2013. 3D reconstitution of nerve-blood vessel networks using skeletal muscle-derived multipotent stem cell sheet pellets. Regen Med 8:437-451. 10.2217/rme.13.30

Tamaki T, Uchiyama Y, Hirata M, Hashimoto H, Nakajima N, Saito K, Terachi T, and Mochida J. 2015. Therapeutic isolation and expansion of human skeletal muscle-derived stem cells for the use of muscle-nerve-blood vessel reconstitution. Front Physiol 6:165. 10.3389/fphys.2015.00165

Tamaki T, Uchiyama Y, Okada Y, Ishikawa T, Sato M, Akatsuka A, and Asahara T. 2005. Functional recovery of damaged skeletal muscle through synchronized vasculogenesis, myogenesis, and neurogenesis by muscle-derived stem cells. Circulation 112:2857-2866.

Uysal AC, and Mizuno H. 2011. Differentiation of adipose-derived stem cells for tendon repair. Methods Mol Biol 702:443-451. 10.1007/978-1-61737-960-4_32

Vieira MH, Oliveira RJ, Eca LP, Pereira IS, Hermeto LC, Matuo R, Fernandes WS, Silva RA, and Antoniolli AC. 2014. Therapeutic potential of mesenchymal stem cells to treat Achilles tendon injuries. Genet Mol Res 13:10434-10449. 10.4238/2014.December.12.5

Wan Y. 2013. Bone marrow mesenchymal stem cells: fat on and blast off by FGF21. Int J Biochem Cell Biol 45:546-549. 10.1016/j.biocel.2012.12.014

Welser JV, Rooney JE, Cohen NC, Gurpur PB, Singer CA, Evans RA, Haines BA, and Burkin DJ. 2009. Myotendinous junction defects and reduced force transmission in mice that lack alpha7 integrin and utrophin. Am J Pathol 175:1545-1554. 
684

685

686

687

688

689

690

691

692

693

694

695

696

697

698

699

700

701

702

703

704

705

706

707

708

709

710

711

712 10.2353/ajpath.2009.090052

Yildirim Y, Saygi B, Kara H, Cabukoglu C, and Esemenli T. 2006. [Tendon holding capacities of the suture materials used in repairing Achilles tendon rupture]. Acta Orthop Traumatol Turc 40:164-168.

Young RG, Butler DL, Weber W, Caplan AI, Gordon SL, and Fink DJ. 1998. Use of mesenchymal stem cells in a collagen matrix for Achilles tendon repair. $J$ Orthop Res 16:406-413. 10.1002/jor.1100160403

Young SW, Patel A, Zhu M, van Dijck S, McNair P, Bevan WP, and Tomlinson M. 2014. Weight-Bearing in the Nonoperative Treatment of Acute Achilles Tendon Ruptures: A Randomized Controlled Trial. J Bone Joint Surg Am 96:1073-1079. 10.2106/JBJS.M.00248

Zhang F, Oswald T, Lin S, Cai Z, Lei M, Jones M, Angel MF, and Lineaweaver WC. 2003. Vascular endothelial growth factor (VEGF) expression and the effect of exogenous VEGF on survival of a random flap in the rat. Br J Plast Surg 56:653-659.

\section{FIGURE LEGENDS}

Figure 1. Macroscopic and schematic images of procedures used in MTJ complete rupture model preparation and sheet-pellet transplantation. (A) An overview of the sheet-pellet preparation. (B) A gel-like state of sheet-pellet being picked up with forceps. Photographs of a left-TA muscle were taken. $C=$ Step 1; D = Step 2; and E = Step 4. Dotted circle in B shows peeling of fibers. White arrows in C show partially sutured skin. Bars $=1 \mathrm{~mm}$.

Figure 2. RT-PCR analysis of Sk-MSC sheet-pellet and its expressions of cytokines immediately prior to transplantation. (A) Expressions of myogenic, neurotrophic, and vasculogenic factor mRNAs was observed, confirming the quality of the sheet-pellet 
713

714

preparation. $\mathrm{bp}=$ base pair. (B) Several cytokines related to the muscle and vascular regeneration was also detected in the culture supernatant of the sheet-pellet, confirming the putative capacity of paracrine.

Figure 3. Differences of operated TA muscle mass and tetanic tension output between the short (4-8 weeks) and long (14-18 weeks) term groups, and these composed individual plots at each measurement point. Average recovery (\%) of operated muscle mass (A) and tetanic tension output (B). In muscle mass recovery in the short term, the SP group showed significantly higher value than C group, and recovery was progressed in the long term group (but not significant) (A). Similarly, significantly higher tension recovery was observed in the long term group (B). (C and D) Individual distributions of recovery was also analyzed in muscle mass and tension. Clear linear relationships between term and recovery are detected on the individual plots of the long term group, but not in the short term group both in the muscle mass (C) and tetanic tension output (D).

Figure 4. Macroscopic observation of surgically treated TA muscles at 5-10 weeks (W) after transplantation in situ and in vitro (after removal). Photographs were taken by synchronizing light conditions as the fluorescence + normal. (A-G) Typical features of sheet-pellet $\left(\mathrm{GFP}^{+}\right)$transplanted muscles. A-C $=$Pattern 1, D $=$Pattern 2, E = Pattern 3, $\mathrm{F}=$ Pattern 4, and G-H = Pattern 5. Arrows in B, D, E, F, G, and H show blood vessels. The relationship between the ingression of blood vessels and $\mathrm{GFP}^{+}$tissues can be also confirmed in the Supplementary Figure S1 on the website. (I and J) Typical features of media transplanted control muscles. White arrows in panel I show the dent in the TA 
737

738

739

740

position. Red arrows in panel $\mathrm{J}$ show fat tissue. When, the media control muscle was isolated (in vitro), a deficit of distal-half of TA muscle with a meager tendon was apparent (arrows in K). The remaining proximal-half of TA (dotted circles in I-K) showed progressive muscle atrophy toward the 6 weeks (compare I and J). Black arrows in $\mathrm{I}$ and $\mathrm{J}$ indicate tibial bone. Bars $=1 \mathrm{~mm}$.

Figure 5. Immunohistochemical detection of engrafted Sk-MSCs in cross-section (operated muscle from Pattern 1, 7 weeks after operation). (A and B) Relationship among the $\mathrm{GFP}^{+}$cell-derived connective tissue, recipient tendon, and muscle fibers. Skeletal muscle fibers were stained with Sk-actin (skeletal muscle actin, A), and tendon and connective tissues were stained with Elastica Van Gieson (B). (C) Endothelial cell staining with $\mathrm{CD} 31$. White arrows show $\mathrm{GFP}^{+} / \mathrm{CD} 31^{+}$cells. Yellow arrows show penetration of $\mathrm{GFP}^{+}$cell-derived connective tissue into the tendon. Dotted line drawing shows the contours of the tendon. (D) Axon staining with Neurofilament 200 (N200). (E) Schwann cell staining with p75. (F) Dystrophin staining for skeletal muscle fibers in the MTJ. Muscle fibers expressing dystrophin (red reactions). Dotted line squares in panel (A) representing small letter $\mathrm{c}, \mathrm{d}$, and e correspond the portions of which the panels C-E was obtained. Higher magnification photographs, showing that the $\mathrm{GFP}^{+} / \mathrm{CD} 31+$ cells and/or $\mathrm{GFP}^{+} / \mathrm{SMA}$ (anti-smooth muscle actin) ${ }^{+}$cells, was also available in the Supplementary Figure S2. Similarly, localization of $\mathrm{GFP}^{+} / \mathrm{p} 75^{+}$cells can be also confirmed in the Supplementary Figure $\mathbf{S 3}$ on the website. $\quad \mathrm{T}=$ tendon. Dotted lines in D and E show the border between connective tissue and muscle fibers. Blue staining $=$ DAPI. Bars in $A$ and $B=200 \mu \mathrm{m}, \mathrm{C}-\mathrm{E}=100 \mu \mathrm{m}$. 
761 Figure 6. Immunohistochemical detection of engrafted Sk-MSCs in longitudinal

762 sections (operated muscle from Pattern 5, 8 weeks after operation). (A) Close

763 relationship between donor-derived $\mathrm{GFP}^{+}$connective tissue and muscle fibers was also

764 apparent in the longitudinal images. (B) $\mathrm{GFP}^{+}$muscle fibers were observed. (C)

765 Vascular smooth muscle staining. (D) Axon staining by N200. (E) Schwann cell staining

766 by p75. (F) Axon and neuromuscular junction staining by N200 and $\alpha$-Bungarotoxin.

767 Dotted circle in panel $\mathrm{F}$ shows the position of neuromuscular junction. $\mathrm{Mf}=$ muscle

768 fiber. Blue staining $=$ DAPI. Bars $=100 \mu \mathrm{m}$.

769

770

Supplementary Figure S1. High magnification photographs of the portions

771

772

773

774

775

776

777

778

779

780

781

782

indicating by the arrows in Figure 4B, D, E and F. Interactions between blood vessels and $\mathrm{GFP}^{+}$tissue are evident.

\section{Supplementary Figure S2. Higher magnification photographs, showing the} $\mathrm{GFP}^{+} / \mathrm{CD} 31^{+}$cells and/or $\mathrm{GFP}^{+} / \mathrm{SMA}^{+}$(anti-smooth muscle actin) cells. These are evidences of the differentiation of $\mathrm{GFP}^{+}$donor cells into vascular endothelial cells (CD31) and vascular smooth muscle cells (SMA).

\section{Supplementary Figure S3. Higher magnification photographs showing the} localization of $\mathrm{GFP}^{+} / \mathrm{p} 75^{+}$cells. These are evidence of the differentiation of $\mathrm{GFP}^{+}$donor cells into Schwann cells. 
783 Table 1. Functional assessment of the operated muscle

\begin{tabular}{|l|l|l|l|l|l|}
\hline \multicolumn{2}{|c|}{} & \multicolumn{2}{|l|}{$\begin{array}{l}\text { Short-term (4-8 weeks) recovery } \\
\text { group }(\mathrm{n}=9)\end{array}$} & \multicolumn{2}{l}{$\begin{array}{l}\text { Long-term (14-18 weeks) } \\
\text { recovery group }(\mathrm{n}=5)\end{array}$} \\
\cline { 2 - 6 } Experimental group & $\begin{array}{l}\text { Muscle mass } \\
(\mathrm{mg})\end{array}$ & $\begin{array}{l}\text { Tetanic tension } \\
\mathrm{N}\left(1 \times 10^{2}\right)\end{array}$ & $\begin{array}{l}\text { Muscle mass } \\
(\mathrm{mg})\end{array}$ & $\begin{array}{r}\text { Tetanic } \\
\text { tension } \mathrm{N} \\
\left(1 \times 10^{2}\right)\end{array}$ \\
\hline \multirow{2}{*}{$\begin{array}{l}\text { SP group } \\
(\mathrm{n}=14)\end{array}$} & Op-side & $31.1 \pm 2.7$ & $20.5 \pm 3.5$ & $39.9 \pm 3.8$ & $35.0 \pm 7.8 *$ \\
\cline { 2 - 6 } & Cont-side & $49.4 \pm 2.3$ & $77.5 \pm 5.1$ & $51.1 \pm 1.0$ & $73.5 \pm 9.7$ \\
\hline $\begin{array}{l}\text { C group } \\
(\mathrm{n}=5)\end{array}$ & Op-side & $26.3 \pm 1.4$ & unmeasurable & Not done & Not done \\
\cline { 2 - 6 } & Cont-side & $53.8 \pm 1.6$ & $79.7 \pm 3.8$ & Not done & Not done \\
\hline
\end{tabular}

784 Values are expressed average \pm SE. $\quad * p<0.05$ 4-weeks vs. 10 weeks tetanus. 

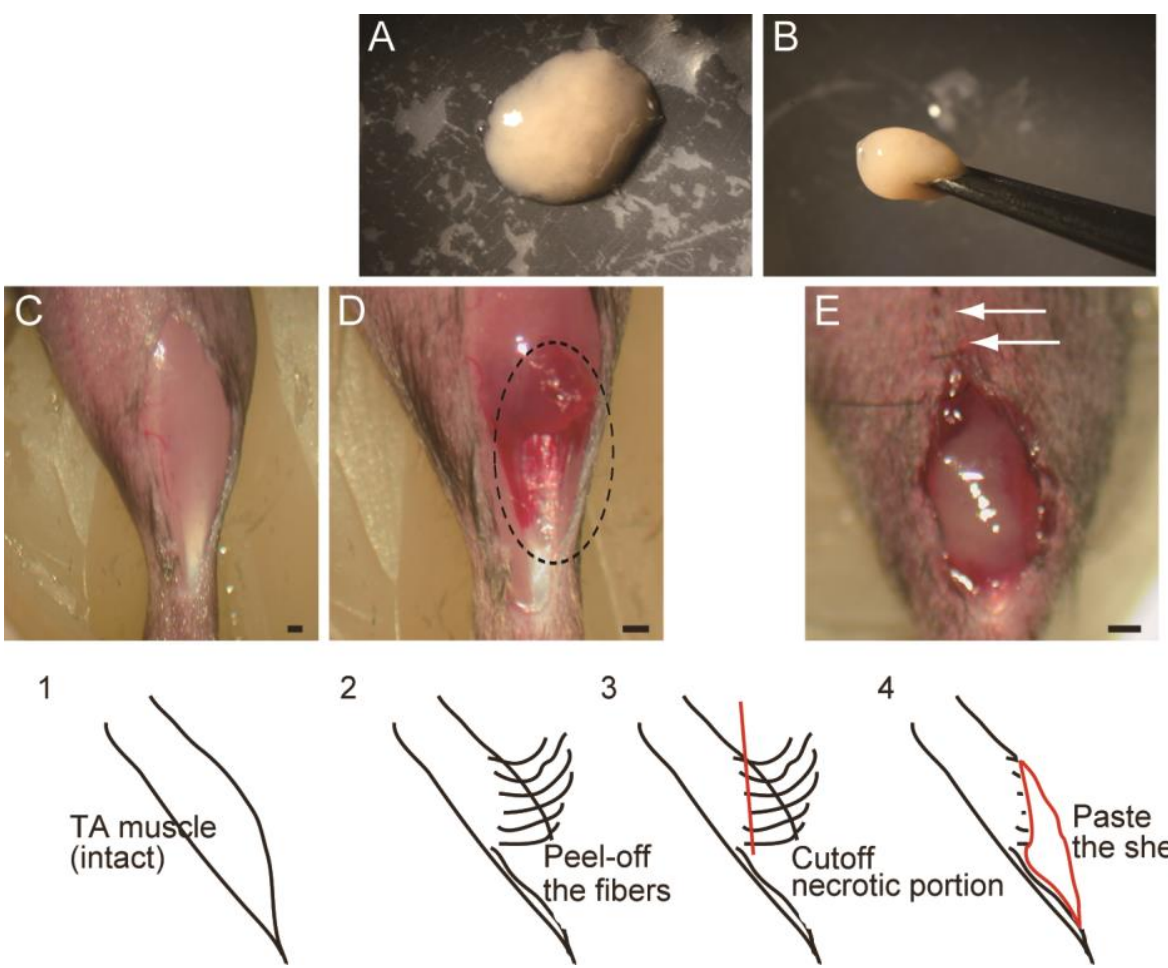

2

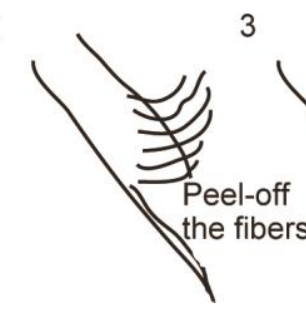

4

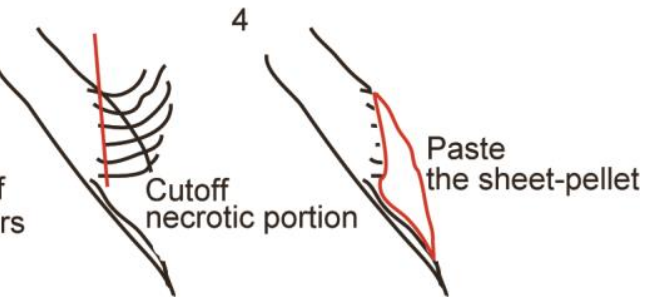

787

Figure 1. Macroscopic and schematic images of procedures used in MTJ complete rupture model preparation and sheet-pellet transplantation. (A) An overview of the sheet-pellet preparation. (B) A gel-like state of sheet-pellet being picked up with forceps. Photographs of a left-TA muscle were taken. $\mathrm{C}=$ Step 1; D = Step 2; and E = Step 4.

792 Dotted circle in B shows peeling of fibers. White arrows in C show partially sutured skin. Bars $=1 \mathrm{~mm}$. 
A Myogenic factors

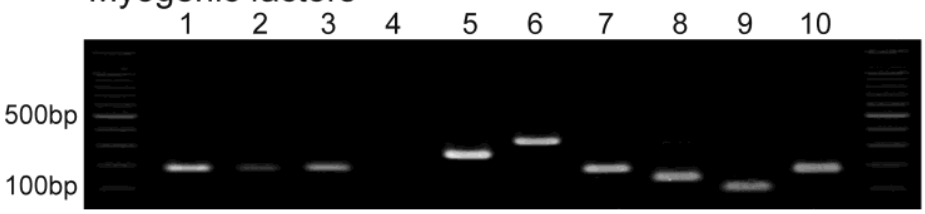

$\begin{array}{ll}\text { 1.MyoD } & \text { 18.Nestin } \\ \text { 2.Myf5 } & \text { 19.Sox10 } \\ \text { 3.Pax7 } & \text { 20.VEGF } \\ \text { 4.Pax3 } & \text { 21.HGF } \\ \text { 5.Myogenin } & \text { 22.PDGF } \\ \text { 6.C-met } & \text { 23.TGFb } \\ \text { 7.Mcad } & \text { 24.EGF } \\ \text { 8.MyH } & \text { 25.FGFb } \\ \text { 9.Desmin } & \text { 26.HPRT } \\ \text { 10.IGF-1 } & \\ \text { 11.NGF } & \\ \text { 12.BDNF } & \\ \text { 13.GDNF } & \\ \text { 14.CNTF } & \\ \text { 15.LIF } & \\ \text { 16.Ninjurin } & \\ \text { 17.Galectin } & \end{array}$

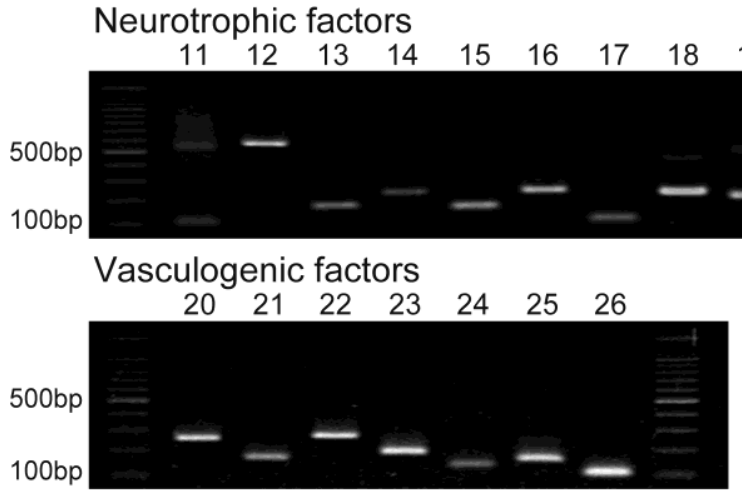

B

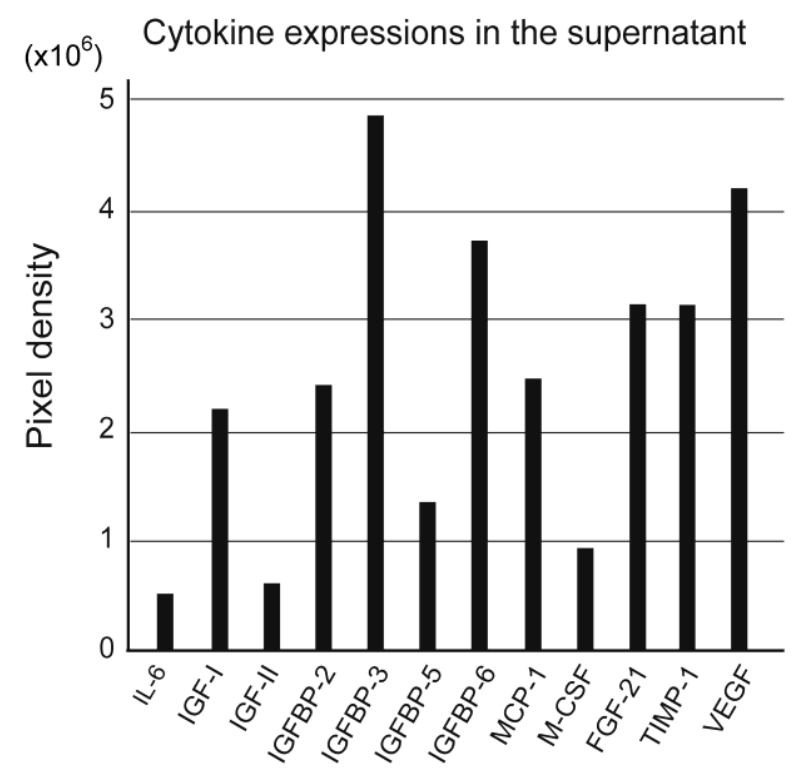

797

798 Figure 2. RT-PCR analysis of Sk-MSC sheet-pellet and its expressions of cytokines

799 immediately prior to transplantation. (A) Expressions of myogenic, neurotrophic, and

800 vasculogenic factor mRNAs was observed, confirming the quality of the sheet-pellet

801 preparation. bp = base pair. (B) Several cytokines related to the muscle and vascular

802 regeneration was also detected in the culture supernatant of the sheet-pellet, confirming

803 the putative capacity of paracrine. 

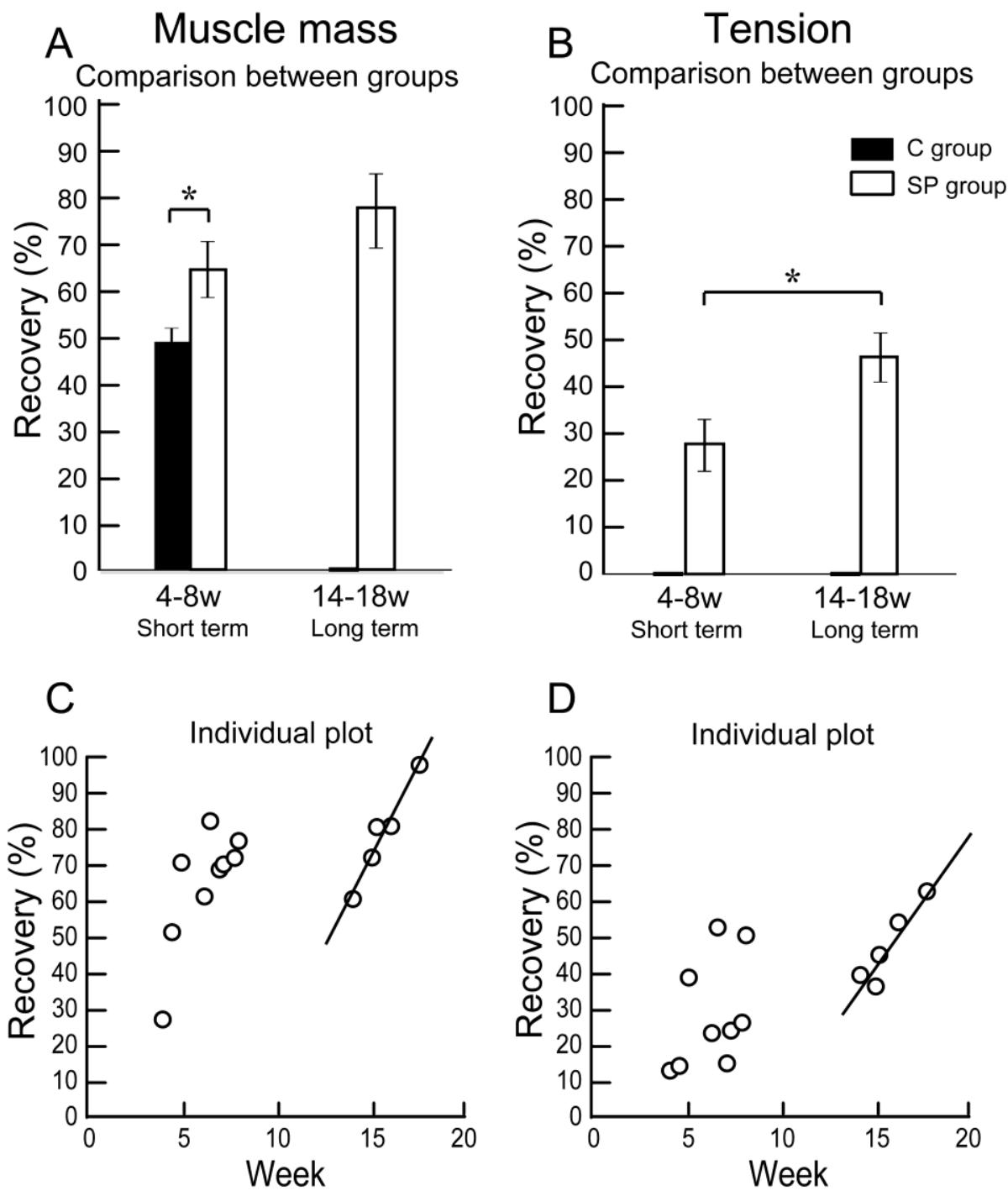

804

805 Figure 3. Differences of operated TA muscle mass and tetanic tension output between the short (4-8 weeks) and long (14-18 weeks) term groups, and these composed individual plots at each measurement point. Average recovery (\%) of operated muscle mass (A) and tetanic tension output (B). In muscle mass recovery in the short term, the SP group showed significantly higher value than $\mathrm{C}$ group, and recovery was progressed in the long term group (but not significant) (A). Similarly, significantly

811 higher tension recovery was observed in the long term group (B). (C and D) Individual

812 distributions of recovery was also analyzed in muscle mass and tension. Clear linear

813 relationships between term and recovery are detected on the individual plots of the long

814 term group, but not in the short term group both in the muscle mass (C) and tetanic

815 tension output (D). 
After sheet-pellet transplantation
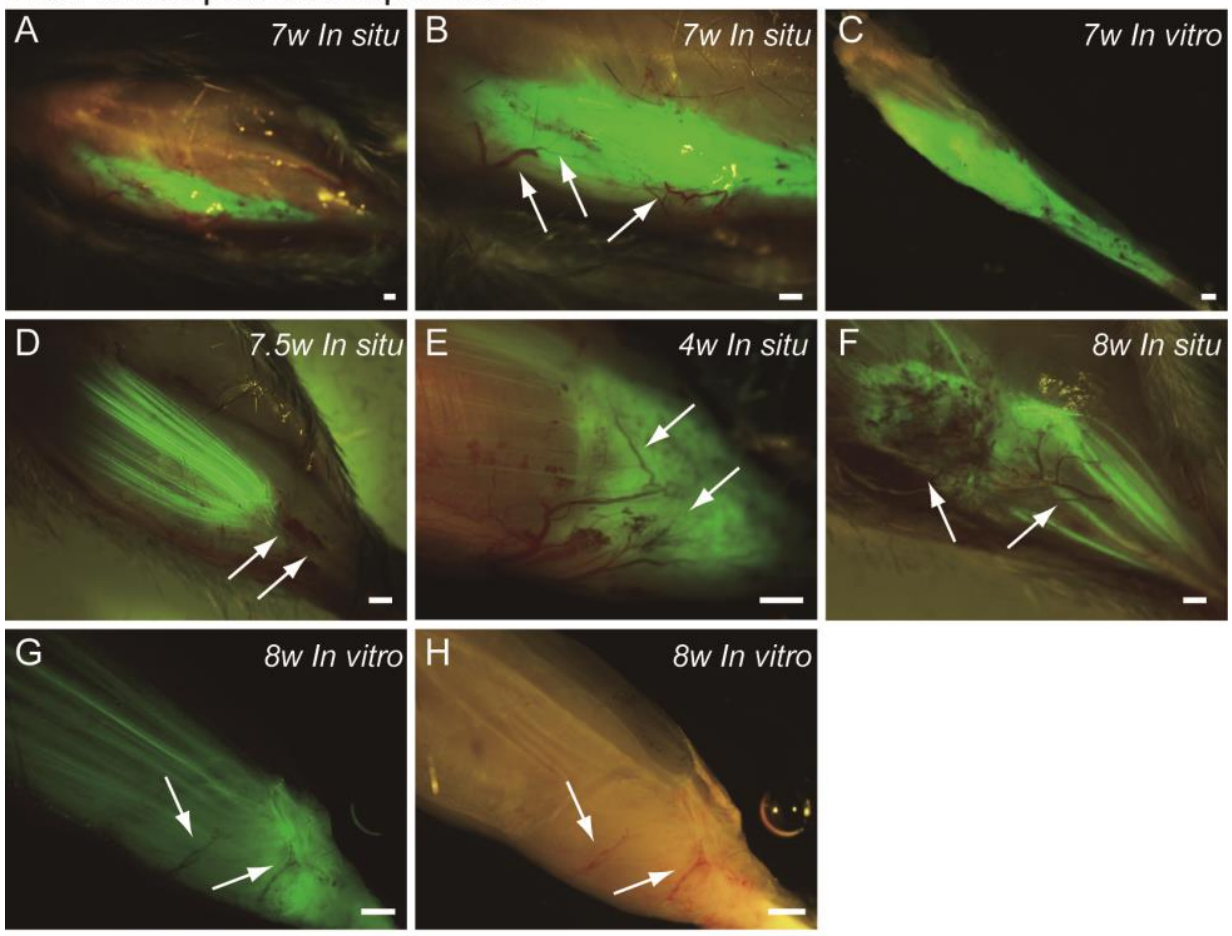

After media transplantation
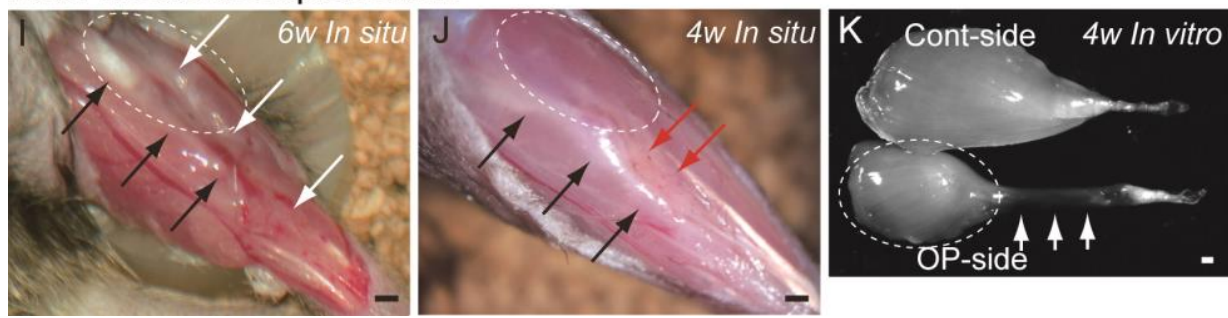

Figure 4. Macroscopic observation of surgically treated TA muscles at 5-10 weeks (W) after transplantation in situ and in vitro (after removal). Photographs were taken by synchronizing light conditions as the fluorescence + normal. (A-G) Typical features of sheet-pellet $\left(\mathrm{GFP}^{+}\right)$transplanted muscles. $\mathrm{A}-\mathrm{C}=$ Pattern $1, \mathrm{D}=$ Pattern 2, $\mathrm{E}=$ Pattern 3, $\mathrm{F}=$ Pattern 4, and G-H = Pattern 5. Arrows in B, D, E, F, G, and H show blood vessels. The relationship between the ingression of blood vessels and $\mathrm{GFP}^{+}$tissues can be also confirmed in the Supplementary Figure S1 on the website. (I and J) Typical features of media transplanted control muscles. White arrows in panel I show the dent in the TA position. Red arrows in panel $\mathrm{J}$ show fat tissue. When, the media control muscle was isolated (in vitro), a deficit of distal-half of TA muscle with a meager tendon was apparent (arrows in K). The remaining proximal-half of TA (dotted circles in I-K) showed progressive muscle atrophy toward the 6 weeks (compare I and J). Black arrows in $\mathrm{I}$ and $\mathrm{J}$ indicate tibial bone. Bars $=1 \mathrm{~mm}$. 

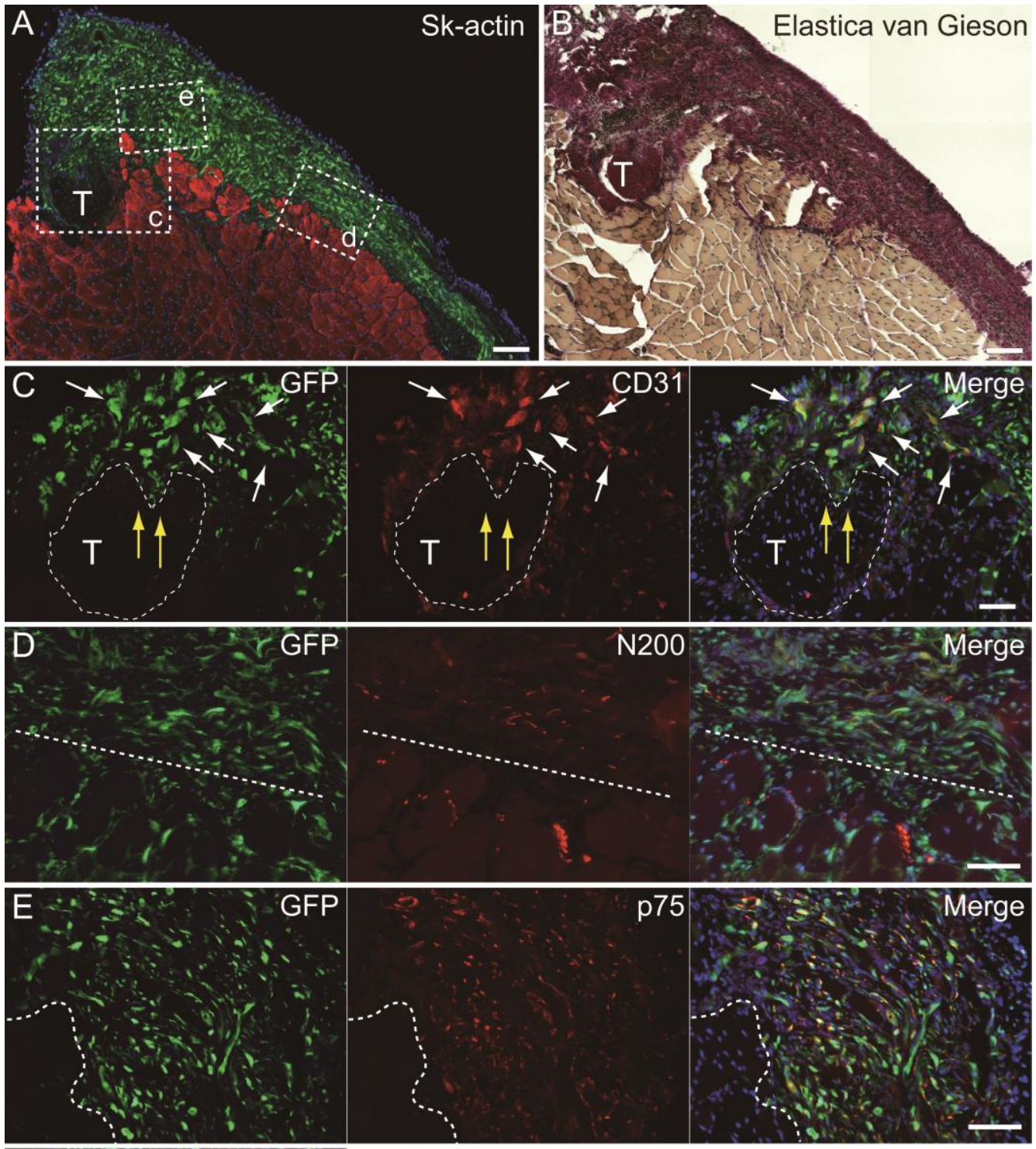

832

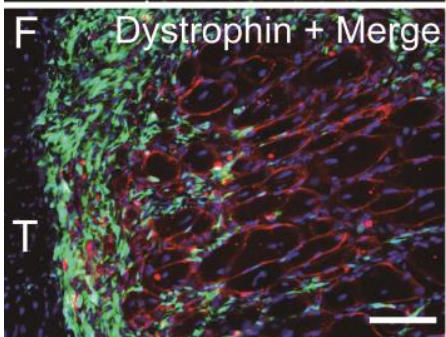

833 Figure 5. Immunohistochemical detection of engrafted Sk-MSCs in cross-section

834 (operated muscle from Pattern 1, 7 weeks after operation). (A and B) Relationship

835 among the $\mathrm{GFP}^{+}$cell-derived connective tissue, recipient tendon, and muscle fibers.

836 Skeletal muscle fibers were stained with Sk-actin (skeletal muscle actin, A), and tendon 837 and connective tissues were stained with Elastica Van Gieson (B). (C) Endothelial cell

838 staining with $\mathrm{CD} 31$. White arrows show $\mathrm{GFP}^{+} / \mathrm{CD} 31^{+}$cells. Yellow arrows show

839 penetration of $\mathrm{GFP}^{+}$cell-derived connective tissue into the tendon. Dotted line drawing

840 shows the contours of the tendon. (D) Axon staining with Neurofilament 200 (N200). 
841 (E) Schwann cell staining with p75. (F) Dystrophin staining for skeletal muscle fibers in

842 the MTJ. Muscle fibers expressing dystrophin (red reactions). Dotted line squares in

843 panel (A) representing small letter c, d, and e correspond the portions of which the

844 panels $\mathrm{C}-\mathrm{E}$ was obtained. Higher magnification photographs, showing that the

$845 \mathrm{GFP}^{+} / \mathrm{CD} 31+$ cells and/or $\mathrm{GFP}^{+} / \mathrm{SMA}$ (anti-smooth muscle actin) ${ }^{+}$cells, was also

846 available in the Supplementary Figure S2. Similarly, localization of $\mathrm{GFP}^{+} / \mathrm{p}^{2} 5^{+}$cells

847 can be also confirmed in the Supplementary Figure $\mathbf{S 3}$ on the website. T= tendon.

848 Dotted lines in D and E show the border between connective tissue and muscle fibers.

849 Blue staining $=$ DAPI. Bars in A and B $=200 \mu \mathrm{m}, \mathrm{C}-\mathrm{E}=100 \mu \mathrm{m}$.

850

851

852

853

854

855

856

857 

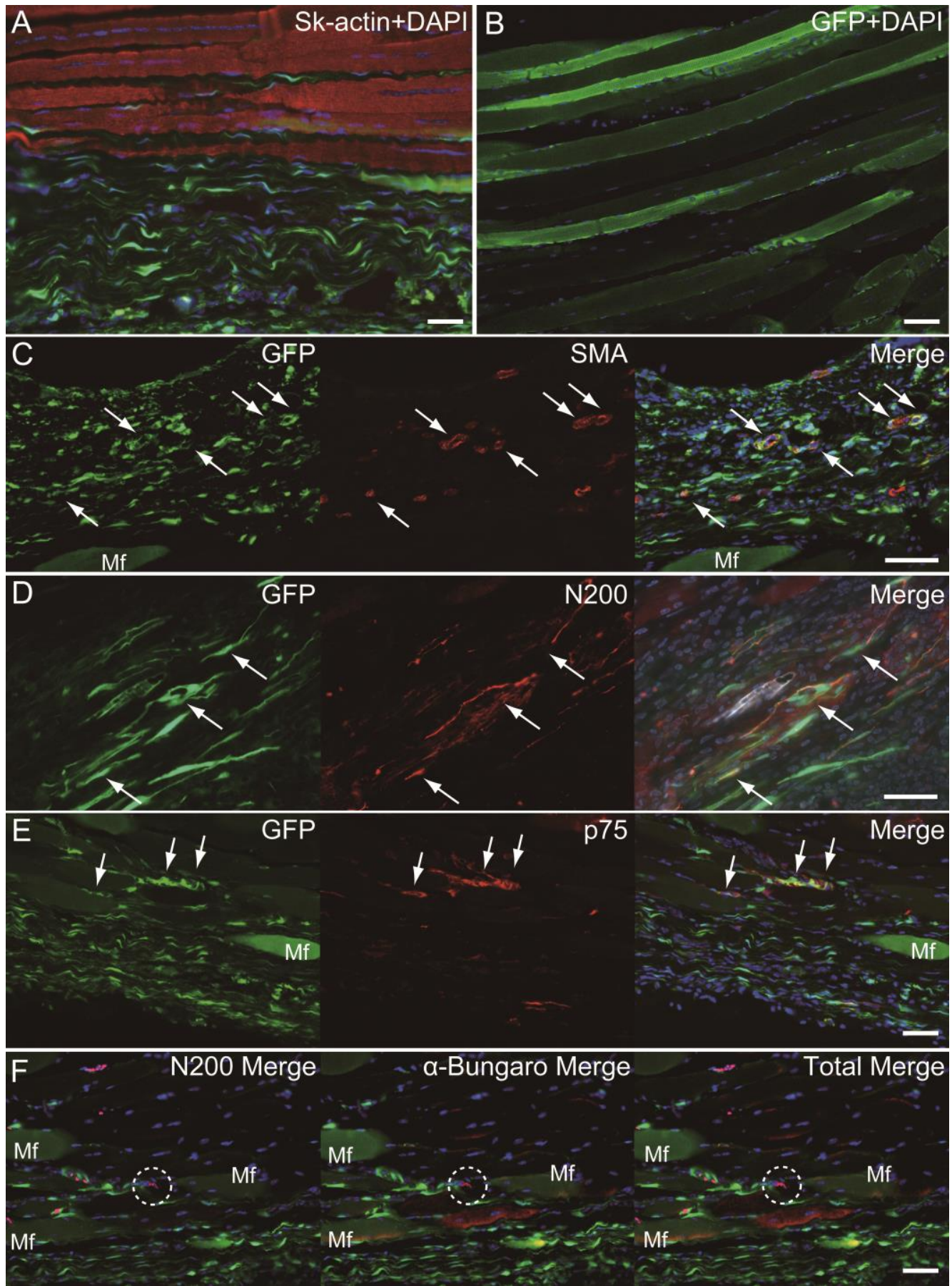

859 Figure 6. Immunohistochemical detection of engrafted Sk-MSCs in longitudinal

860 sections (operated muscle from Pattern 5, 8 weeks after operation). (A) Close

861 relationship between donor-derived $\mathrm{GFP}^{+}$connective tissue and muscle fibers was also

862 apparent in the longitudinal images. (B) $\mathrm{GFP}^{+}$muscle fibers were observed. (C)

863 Vascular smooth muscle staining. (D) Axon staining by N200. (E) Schwann cell staining

864 by p75. (F) Axon and neuromuscular junction staining by N200 and $\alpha$-Bungarotoxin.

865 Dotted circle in panel $\mathrm{F}$ shows the position of neuromuscular junction. $\mathrm{Mf}=$ muscle

866 fiber. Blue staining $=$ DAPI. Bars $=100 \mu \mathrm{m}$. 
Arrows in B

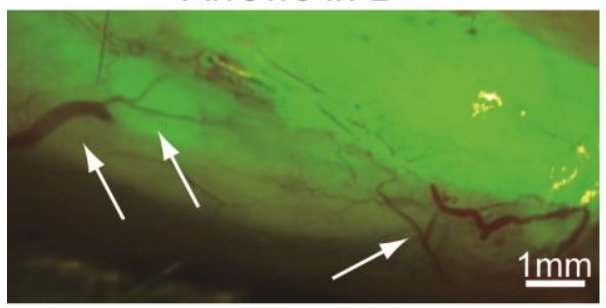

Arrows in $\mathrm{E}$

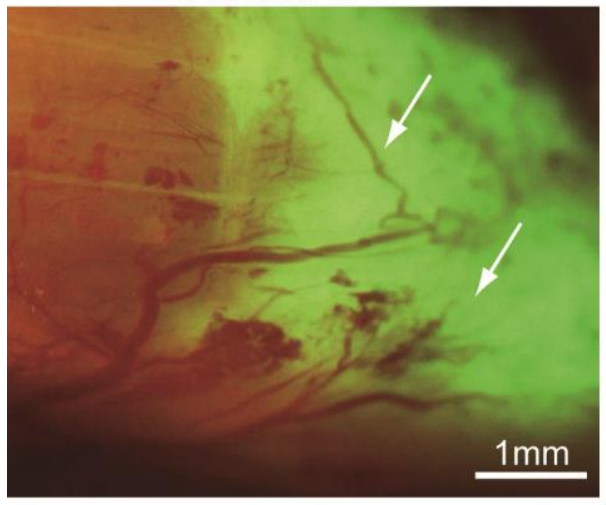

$1 \mathrm{~mm}$

867

868

869

870

871

872

873 and $\mathrm{GFP}^{+}$tissue are evident.
Arrows in D

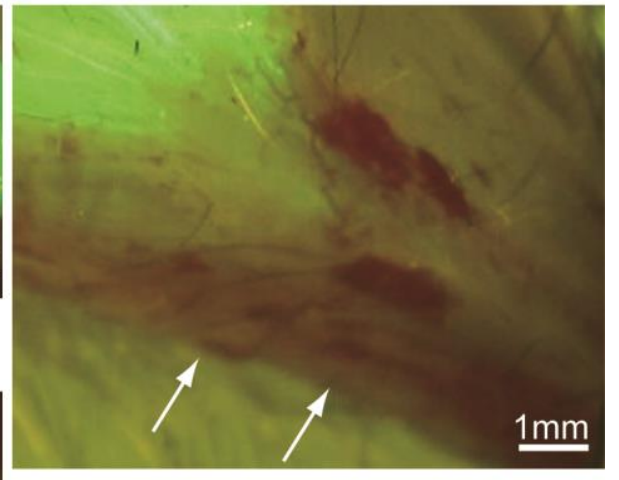

Arrows in $\mathrm{F}$

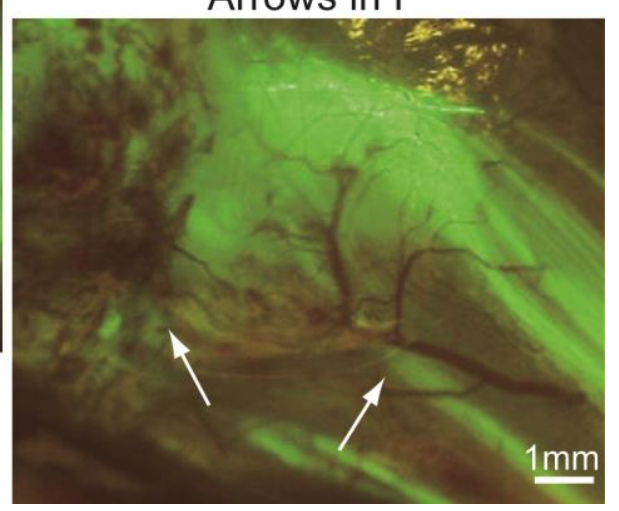

Supplementary Figure S1. High magnification photographs of the portions indicating by the arrows in Figure 4B, D, E and F. Interactions between blood vessels 

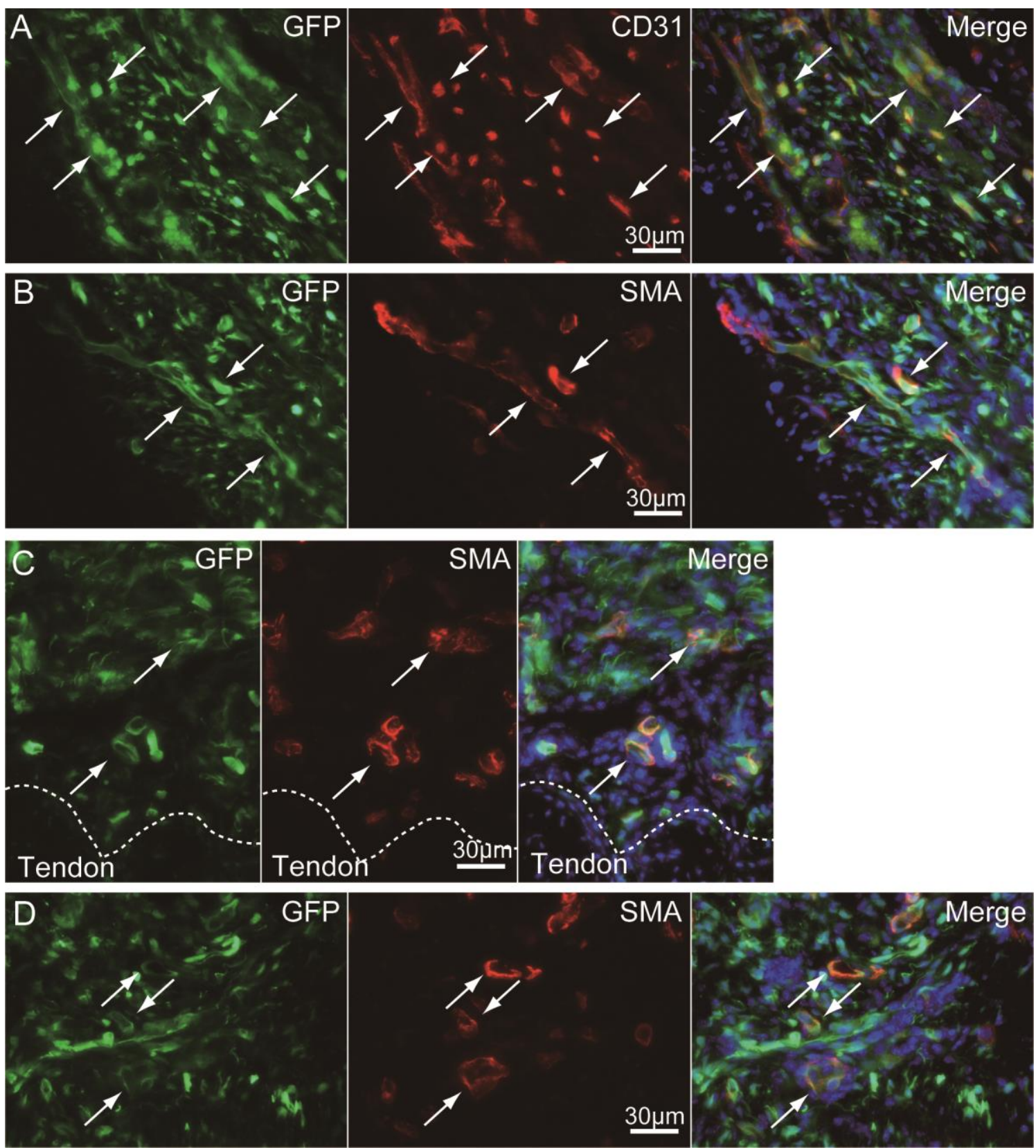

875 Supplementary Figure S2. Higher magnification photographs, showing the

$876 \mathrm{GFP}^{+} / \mathrm{CD} 31^{+}$cells and/or $\mathrm{GFP}^{+} / \mathrm{SMA}^{+}$(anti-smooth muscle actin) cells. These are

877 evidences of the differentiation of $\mathrm{GFP}^{+}$donor cells into vascular endothelial cells

878 (CD31) and vascular smooth muscle cells (SMA). 


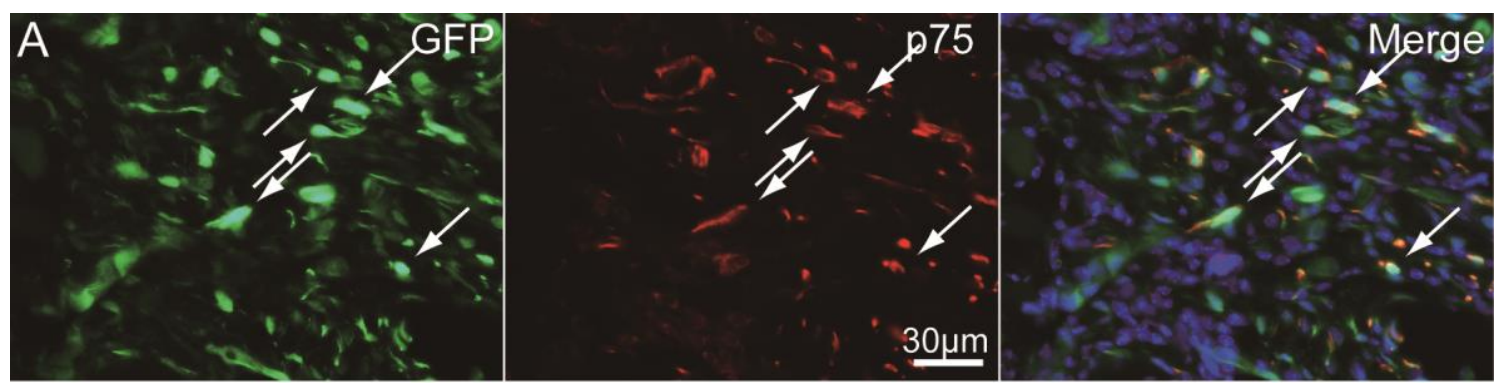

879
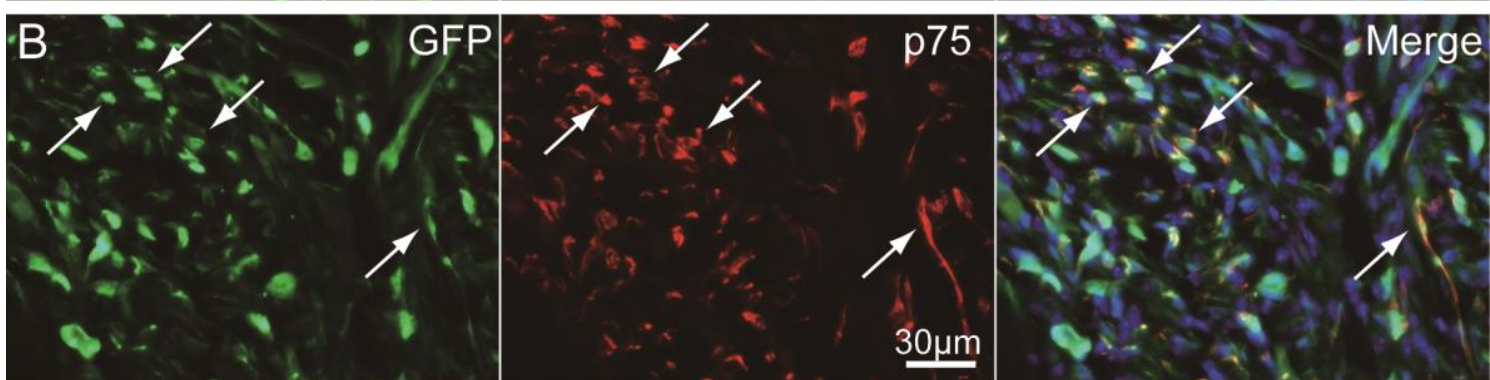

880

Supplementary Figure S3. Higher magnification photographs showing the

881 localization of $\mathrm{GFP}^{+} / \mathrm{p} 75^{+}$cells. These are evidence of the differentiation of $\mathrm{GFP}^{+}$donor 882 cells into Schwann cells.

883 
Supplementary Table S1. Specific primers for mice.

\begin{tabular}{|c|c|c|c|c|c|}
\hline $\begin{array}{l}\mathrm{N} \\
\mathrm{o}\end{array}$ & $\begin{array}{l}\text { Gene name (full name and/or typical } \\
\text { role) }\end{array}$ & $\begin{array}{l}\text { product } \\
\text { size } \\
\text { (bp) }\end{array}$ & Forward primer & Reverse primer & $\begin{array}{l}\text { Utilization } \\
\text { purpose }\end{array}$ \\
\hline 1 & $\begin{array}{l}\text { MyoD (myogenic regulatory } \\
\text { factors) }\end{array}$ & 184 & $\begin{array}{l}\text { GGCCACTCAGGTCTCAGG } \\
\text { TGT }\end{array}$ & $\begin{array}{l}\text { TGTTGCACTACACAGCATG } \\
\text { CCT }\end{array}$ & \multirow{10}{*}{$\begin{array}{l}\text { Myogenic } \\
\text { determination } \\
\text { and } \\
\text { differentiation } \\
\text { markers }\end{array}$} \\
\hline 2 & Myf5 (myogenic regulatory factors) & 179 & $\begin{array}{l}\text { TTAGCAAACCATGAACAC } \\
\text { GAAACA }\end{array}$ & $\begin{array}{l}\text { AAGGGGGCTTCATTTACC } \\
\text { AGG }\end{array}$ & \\
\hline 3 & $\begin{array}{l}\text { Pax7 (paired box transcription } \\
\text { factors, also known as satellite cell } \\
\text { marker) }\end{array}$ & 192 & $\begin{array}{l}\text { CCCAACAGGTTTTCCCAAC } \\
\text { TG }\end{array}$ & $\begin{array}{l}\text { CGGCCTTCTTCTAGGTTCT } \\
\text { GCT }\end{array}$ & \\
\hline 4 & $\begin{array}{l}\text { Pax3 (paired box transcription } \\
\text { factors relate to embryonic muscle } \\
\text { development) }\end{array}$ & 256 & $\begin{array}{l}\text { TGGACAGTCTGCCCACATC } \\
\text { TCAGC }\end{array}$ & $\begin{array}{l}\text { GGGAGCCTGTGCTGTAGC } \\
\text { AATCAG }\end{array}$ & \\
\hline 5 & $\begin{array}{l}\text { Myogenin (myogenic regulatory } \\
\text { factors) }\end{array}$ & 262 & $\begin{array}{l}\text { TACGTCCATCGTGGACAG } \\
\text { CAT }\end{array}$ & $\begin{array}{l}\text { TCAGCTAAATTCCCTCGCT } \\
\text { GG }\end{array}$ & \\
\hline 6 & $\begin{array}{l}\text { c-met (hepatocyte growth factor } \\
\text { receptor, which is present in } \\
\text { quiescent satellite cell) }\end{array}$ & 337 & $\begin{array}{l}\text { CCAAGCCGCGTATGTCAG } \\
\text { TAAA }\end{array}$ & $\begin{array}{l}\text { AATAAGTCGACGCGCTGC } \\
\text { A }\end{array}$ & \\
\hline 7 & $\begin{array}{l}\text { M-cad (M-cadherin, a } \\
\text { Ca2+-dependent cell adhesion } \\
\text { molecule which is present in } \\
\text { quiescent satellite cell) }\end{array}$ & 193 & $\begin{array}{l}\text { GGGCTCTCTCTTGGGATGT } \\
\text { G }\end{array}$ & $\begin{array}{l}\text { CTTCTGCACTCTGCCAGGA } \\
\text { C }\end{array}$ & \\
\hline 8 & $\begin{array}{l}\text { MyH (skeletal muscle myosin } \\
\text { heavy chain, cell differentiation } \\
\text { marker) }\end{array}$ & 152 & $\begin{array}{l}\text { TCAGGAAAGCCCAGCATG } \\
\text { AG }\end{array}$ & $\begin{array}{l}\text { TGCACCAGGAGGTCTTGCT } \\
\text { C }\end{array}$ & \\
\hline 9 & $\begin{array}{l}\text { Desmin (Muscle relate intermediate } \\
\text { filament protein, cell differentiation } \\
\text { marker) }\end{array}$ & 106 & $\begin{array}{l}\text { AGGGTCAGGACCGAGTTT } \\
\text { GTG }\end{array}$ & $\begin{array}{l}\text { GCCATGAGGGCAGTTTTC } \\
\text { AG }\end{array}$ & \\
\hline 10 & IGF1 (Insulin-like growth factor-1) & 185 & $\begin{array}{l}\text { CTGCTTGCTCACCTTCACC } \\
\text { AG }\end{array}$ & $\begin{array}{l}\text { TCCGGAAGCAACACTCAT } \\
\text { CC }\end{array}$ & \\
\hline 11 & $\begin{array}{l}\text { NGF (Nerve growth factor, } \\
\text { peripheral nerve growth and trophic } \\
\text { factor) }\end{array}$ & 106 & $\begin{array}{l}\text { TGCACCACGACTCACACCT } \\
\text { TC }\end{array}$ & $\begin{array}{l}\text { TCCTGCTGAGCACACACA } \\
\text { CAC }\end{array}$ & \multirow{9}{*}{$\begin{array}{l}\text { Peripheral nerve } \\
\text { growth and trophic } \\
\text { factors }\end{array}$} \\
\hline 12 & $\begin{array}{l}\text { BDNF (Brain-derived neurotrophic } \\
\text { factor) }\end{array}$ & 582 & $\begin{array}{l}\text { GGGACTCTGGAGAGCGTG } \\
\text { AAT }\end{array}$ & $\begin{array}{l}\text { CCTTATGAATCGCCAGCCA } \\
\text { AT }\end{array}$ & \\
\hline 13 & $\begin{array}{l}\text { GDNF (Glial cell-derived } \\
\text { neurotrophic factor, peripheral } \\
\text { nerve growth and trophic factor) }\end{array}$ & 180 & $\begin{array}{l}\text { GTGAATCGGCCGAGACAA } \\
\text { TG }\end{array}$ & $\begin{array}{l}\text { CACACCGTTTAGCGGAAT } \\
\text { GC }\end{array}$ & \\
\hline 14 & $\begin{array}{l}\text { CNTF (Ciliary neurotrophic factor, } \\
\text { peripheral nerve growth and trophic } \\
\text { factor) }\end{array}$ & 241 & $\begin{array}{l}\text { TTTCTGCCTTCGCCTACCA } \\
\text { G }\end{array}$ & $\begin{array}{l}\text { TTGGCCCCATAATGGCTCT } \\
\text { C }\end{array}$ & \\
\hline 15 & $\begin{array}{l}\text { LIF (Leukemia inhibitory factor, } \\
\text { peripheral nerve growth and trophic } \\
\text { factor) }\end{array}$ & 169 & $\begin{array}{l}\text { ATCGGATGGTCGCATACCT } \\
\text { G }\end{array}$ & $\begin{array}{l}\text { CCCACACGGTACTTGTTGC } \\
\text { AC }\end{array}$ & \\
\hline 16 & $\begin{array}{l}\text { Ninjurin (nerve injury-induced } \\
\text { protein) }\end{array}$ & 243 & $\begin{array}{l}\text { GGAGCAGGGCAATGATTT } \\
\text { CG }\end{array}$ & $\begin{array}{l}\text { GCCACGTCCATTACAGGCT } \\
\text { TC }\end{array}$ & \\
\hline 17 & $\begin{array}{l}\text { Galectin-1 (Initial axonal growth } \\
\text { regulator in peripheral nerves after } \\
\text { axotomy) }\end{array}$ & 109 & $\begin{array}{l}\text { TGTCTCAAAGTTCGGGGA } \\
\text { GAGG }\end{array}$ & $\begin{array}{l}\text { GGGCATTGAAGCGAGGAT } \\
\text { TG }\end{array}$ & \\
\hline 18 & $\begin{array}{l}\text { Nestin (Nerve relate intermediate } \\
\text { filament protein, cell differentiation } \\
\text { marker) }\end{array}$ & 233 & $\begin{array}{l}\text { GCTCTGGGCCAGCACTCTT } \\
\text { AG }\end{array}$ & $\begin{array}{l}\text { TGTAGACAGGCAGGGCTA } \\
\text { GCA }\end{array}$ & \\
\hline 19 & $\begin{array}{l}\text { Sox10 (transcription factor relate to } \\
\text { Schwann cell-development) }\end{array}$ & 213 & $\begin{array}{l}\text { TCCCCATGTTCTTCCCATC } \\
\text { C }\end{array}$ & $\begin{array}{l}\text { CAAAGGGTGCAAGGCAAA } \\
\text { GG }\end{array}$ & \\
\hline 20 & $\begin{array}{l}\text { VEGF (Vascular endothelial growth } \\
\text { factor, vascular relating growth } \\
\text { factor) }\end{array}$ & 260 & $\begin{array}{l}\text { TCAGGGTTTCGGGAACCA } \\
\text { GAC }\end{array}$ & $\begin{array}{l}\text { TTCCGGGCTTGGCGATTTA } \\
\text { G }\end{array}$ & \multirow{2}{*}{$\begin{array}{l}\text { Vascular relating } \\
\text { growth factor }\end{array}$} \\
\hline 21 & $\begin{array}{l}\text { HGF (Hepatocyte growth factor, } \\
\text { common elements to muscle and } \\
\text { vascular growth) }\end{array}$ & 169 & $\begin{array}{l}\text { TCAGCACCATCAAGGCAA } \\
\text { GG }\end{array}$ & $\begin{array}{l}\text { GATGGCACATCCACGACC } \\
\text { AG }\end{array}$ & \\
\hline
\end{tabular}




\begin{tabular}{|c|c|c|c|c|c|}
\hline 22 & $\begin{array}{l}\text { PDGF-b (Platelet-derived growth } \\
\text { factor-b, vascular relating growth } \\
\text { factor) }\end{array}$ & 271 & $\begin{array}{l}\text { AGCCAAGACGCCTCAAGC } \\
\text { TC }\end{array}$ & $\begin{array}{l}\text { GGGTGAGGGAAGCACCAT } \\
\text { TG }\end{array}$ & \\
\hline 23 & $\begin{array}{l}\text { TGFb (Transforming growth } \\
\text { factor-b, vascular relating growth } \\
\text { factor) }\end{array}$ & 195 & $\begin{array}{l}\text { CCAAGGGCTACCATGCCA } \\
\text { AC }\end{array}$ & $\begin{array}{l}\text { ACTGCTCCACCTTGGGCTT } \\
\mathrm{G}\end{array}$ & \\
\hline 24 & $\begin{array}{l}\text { EGF (Epidermal Growth Factor, } \\
\text { common elements to muscle and } \\
\text { nerve growth) }\end{array}$ & 137 & $\begin{array}{l}\text { TGCGGATGGTACGAATGG } \\
\text { TG }\end{array}$ & $\begin{array}{l}\text { GTGGAATCCAGCAGCTTT } \\
\text { GC }\end{array}$ & \\
\hline 25 & $\begin{array}{l}\text { FGF2 (basic fibroblast growth } \\
\text { factor, common elements to muscle } \\
\text { and nerve growth) }\end{array}$ & 161 & $\begin{array}{l}\text { GCCAACCGGTACCTTGCTA } \\
\text { TG }\end{array}$ & $\begin{array}{l}\text { TGCCCAGTTCGTTTCAGTG } \\
\mathrm{C}\end{array}$ & \\
\hline 26 & $\begin{array}{l}\text { HPRT (hypoxanthine guanine } \\
\text { phosphoribosyl transferase) }\end{array}$ & 111 & $\begin{array}{l}\text { GCAAACTTTGCTTTCCCTG } \\
\text { GTTAAG }\end{array}$ & $\begin{array}{l}\text { CAACAAAGTCTGGCCTGT } \\
\text { ATCCA }\end{array}$ & $\begin{array}{l}\text { House-keeping } \\
\text { control gene }\end{array}$ \\
\hline
\end{tabular}

884

885 